\title{
Policy capacity and governance conditions for implementing sustainable development goals in Brazil
}

\author{
Natália Massaco Koga ${ }^{1,2}$ \\ Fernando Filgueiras ${ }^{2,4}$ \\ Maricilene Isaira Baia do Nascimento ${ }^{1}$ \\ Natasha Borali ${ }^{4}$ \\ Victor Bastos Lima ${ }^{5}$
}

${ }^{1}$ Institute of Applied Economic Research (Ipea) Brasília - DF, Brazil ${ }^{2}$ Federal University of Minas Gerais (UFMG) Belo Horizonte - MG, Brazil

${ }^{3}$ University of Brasília (UnB), Brasília - DF, Brazil ${ }^{4}$ Getúlio Vargas Fondation (FGV), Brasília - DF, Brazil ${ }^{5}$ University of São Paulo (USP), São Paulo - SP, Brazil

This article examines governance conditions for implementing the United Nations' Sustainable Development Goals (SDGs) in Brazil. The SDGs are a commitment (signed and adopted in September 2015 by 193 countries) to achieve 17 key milestones by 2030 for formulating and implementing public policies that promote economic, social, and environmental development. Yet the Goals' multifaceted and imbricated nature poses expressive challenges. One argues that the SDGs provide a rich set of interconnected policies to address key aspects of the governance debate, such as the capacities in a complex policy-implementation context; the association between administrative and relational policy capacities; and the dynamics of governance tools. This investigation entails quanti-qualitative analysis based on data produced by semi-structured interviews and a survey with a random sample of the Brazilian federal bureaucracy, answered by 2,000 individuals. The main findings are that the SDGs require a governance strategy capable of building capacity for promoting collaboration among state and society, horizontal and vertical coordination, and data and information for developing analytical capabilities. In sum, SDGs require higher levels of capacities, leadership, and proper institutional design to reach the necessary levels of collaboration for producing coherent and integrated policies, so leadership materializes as the main critical condition for SDGs' implementation in Brazil.

Keywords: Sustainable Development Goals, governance, policy capacities 


\section{Capacidade para produção de políticas públicas e condições de governança para implementação dos Objetivos de Desenvolvimento Sustentável no Brasil}

Este artigo examina as condições de governança para a implementação no Brasil dos Objetivos de Desenvolvimento Sustentável (ODS) das Nações Unidas. Os ODS são um compromisso (assinado e adotado em setembro de 2015 por 193 países) de alcançar 17 Objetivos até 2030 para a formulação e implementação de políticas públicas que promovam o desenvolvimento econômico, social e ambiental. No entanto, a natureza multifacetada e imbricada dos ODS traz desafios expressivos. Argumenta-se que os ODS fornecem um rico conjunto de políticas interligadas para abordar aspectos-chave do debate sobre a governança, tais como as capacidades em um contexto complexo de implementação de políticas; a associação entre capacidades administrativas e relacionais de produção de políticas; e a dinâmica dos instrumentos de governança. Esta pesquisa envolve uma análise quanti-quali baseada em dados produzidos por meio de entrevistas semiestruturadas e um questionário aplicado a uma amostra aleatória da burocracia federal brasileira, respondida por 2 mil indivíduos. As principais conclusões alcançadas são que os ODS exigem uma estratégia de governança capaz de criar capacidade para promover a colaboração entre o Estado e a sociedade, coordenação horizontal e vertical, e dados e informações para o desenvolvimento de capacidades analíticas. Em suma, os ODS exigem níveis mais elevados de capacidades do Estado, liderança e desenho institucional adequado para alcançar os níveis necessários de colaboração para produzir políticas coerentes e integradas. Além dessas condições, a liderança emerge como a principal condição crítica para a implementação dos ODS no Brasil.

Palavras-chave: Objetivos de Desenvolvimento Sustentável, governança, capacidades para produção de políticas públicas

\section{Capacidad para la producción de políticas públicas y condiciones de gobernanza para la implementación de los Objetivos de Desarrollo Sostenible en Brasil}

Este artículo examina las condiciones de gobernanza para la implementación en Brasil de los Objetivos de Desarrollo Sostenible (ODS) de las Naciones Unidas. Los ODS son un compromiso (firmado y adoptado en septiembre de 2015 por 193 países) de alcanzar 17 objetivos hasta 2030 para la formulación e implementación de políticas públicas que promuevan el desarrollo económico, social y ambiental. Sin embargo, la naturaleza multifacética e imbricada de los ODS plantea desafíos expresivos. Se argumenta que los ODS proporcionan un amplio conjunto de políticas interconectadas para abordar aspectos clave del debate sobre la gobernanza, como las capacidades en un contexto complejo de implementación de políticas; la asociación entre las capacidades administrativas y relacionales para la producción de políticas; y la dinámica de los instrumentos de gobernanza. Esta investigación aplica un análisis quali-quanti basado en datos producidos a partir de entrevistas semiestructuradas y un cuestionario aplicado a una muestra aleatoria de la burocracia federal brasileña, respondida por 2.000 personas. Las principales conclusiones son que los ODS requieren una estrategia de gobernanza capaz de crear la capacidad de promover la colaboración entre el Estado y la sociedad, la coordinación horizontal y vertical, y los datos y la información para el desarrollo de capacidades analíticas. En conjunto, los ODS requieren mayores niveles de capacidades estatales, liderazgo y diseño institucional adecuado para lograr los niveles necesarios de colaboración para producir políticas coherentes e integradas. Además de estas condiciones, el liderazgo surge como la principal condición crítica para la implementación de los ODS en Brasil.

Palabras clave: Objetivos de Desarrollo Sostenible, gobernanza, capacidades para la producción de políticas públicas 


\section{Introduction}

On September 25, 2015, with the support of the United Nations Organizations (UN), 193 world leaders approved Agenda 2030 of the Sustainable Development Goals (SDGs) (BRAZIL, 2014). This Agenda consists of a collaborative action plan to grapple with extreme poverty, social inequalities, and climate change (UNITED NATIONS, 2015).

SDGs have been characterized in official discourses as more comprehensive, challenging, and audacious than the Millennium Development Goals (MDGs). The Agenda 2030 contains 17 goals, unraveled in 169 objectives that associate economic growth, social development, and environmental protection. This broader Agenda rescues and imbues a comprehensive civilizing commitment by advocating for a development model and public policies.

However, the SDGs' multifaceted and imbricated nature poses complicated challenges to the 193 countries that signed a commitment to achieve the UN 17 SDG by 2030. Brazil's strong involvement with seminal international agreements and debates to conceive the SDGs', such as the MDG and UN Conference on Sustainable Development $($ Rio+20), raises expectations on SDGs' implementation in the country.

In 2016, through Presidential Decree No. 8,892/2016, the National Commission for the Sustainable Development Goals (CNODS) was created-the main Brazilian formal governance body responsible for establishing the process of implementing Agenda 2030 in Brazil. The Commission is integrated into the structure of the Government Secretariat of the Presidency of the Republic, with the purpose of internalizing, disseminating, and offering transparency to the process of implementing Agenda 2030 through articulation, mobilization, and dialogue with the three levels of government and civil society (BRAZIL, 2016).

CNODS encourages the creation of institutional mechanisms for implementing, monitoring, and evaluating the SDGs' agenda, as well as forms of territorialization and participatory decision-making processes. CNODS' discourse responds to the Agenda's general statement that achieving its goals and objectives requires transversality and intersectorality among Brazilian public policies. It is no longer a matter of addressing problems through sectoral policies implemented in isolation by federal organizations. It is about identifying and directing state capacities to achieve goals agreed upon in Agenda 2030 
Looking at the governance literature and data from the Brazilian federal government's context, analytical and relational capacities to implement public policy are unevenly distributed across the country's federal agencies; what becomes evident is that some capacities emerge as the main critical condition to implement SDG in Brazil. With this in mind, this investigation identifies and examines existing governance arrangements and critical capacities to implement SDGs in Brazil, particularly from the federal government's perspective. This paper seeks answers to the following questions:

- What are the critical conditions to implement SDGs in Brazil?

- $\quad$ Do all stakeholders from the federal government have the organizational capacity to participate in a meaningful way?

- Is there sufficient leadership to guide the process?

\section{Theory: governance tools and policy capacities}

Governance is an institutional arrangement that allows society to improve the state capacity and thus the production of efficiency and legitimacy in a political system (Peters \& Pierre, 2008). That is the definition built by the first wave of governance studies which sought to understand the constituent elements of improving the state's capacity to implement public policies. According to that view, governance is about collective interests in governing, involving the state and society to define and implement collective objectives.

The governance concept is not a novelty. However, contemporary reforms in public administration and the political system consider the governance perspective because it shifts away from conceiving government as a hierarchical role of enforcing society's action toward a steering role in government's relationship with the market and societal networks (STOKER, 1997; 2019). A second wave arose on developing the concept of governance based on a social perspective (RHODES, 1997). In the face of the fragmentation of society's interests, this governance perspective considers that social actors are capable of building networks and influencing decisions and policy implementation (RHODES, 2007, 2012). Networks are governance structures that can expand the role of public administration. Rather than being government-centric, network governance is an interactional complexity structure among the state and society. It is thus an approach that can improve public institutions through political participation and 
growth of democratic channels (Sörensen \& Torfing, 2005).

This interactive concept for governance is not limited to the context of local societies. It also extends to global aspects. The expansion of international markets requires the existence of institutions to ensure the conditions for governance (ROSENAU, 1995, 1999). Public policies are also formulated in global arenas, promoting the diffusion of common objectives, formulation and decision-making processes, and monitoring and evaluation of global policy (STONE, 2019).

The definition of governance transcends managerial and administrative mechanisms. It represents a process that connects mechanisms of public administration to the political and infrastructural aspect of authority (FUKUYAMA, 2013). Thus, state capacity and the autonomy of public organizations are vital and associated elements of governance's approach. State capacity must be related to the degree of institutional autonomy. Autonomy consists of the institutions' capacity to carry out public actions, regardless of particular directives. The interaction of capacity and autonomy constitutes an optimum point at which it is possible to constitute government and administration processes of the highest quality (FUKUYAMA, 2013).

Unlike New Public Management, the governance perspective does not provide a universal solution for public sector reforms. The central concern is to promote a more robust institutional arrangement that enables improving the quality of public services in the context of a democratic public administration subjected to mechanisms of compliance and accountability (MUNGIU-PIPPIDI, 2015). The main element that defines New Public Management is the construction of bureaucracy's institutional autonomy (BARZELAY, 1992). By contrast, a governance perspective sustains that institutional development occurs according to the context. It questions universal solutions' applicability for distinct political and economic contexts, especially in the case of developing countries (GRINDLE, 2004; POLLITT \& BOUCKAERT, 2004).

While the New Public Management approach considers that autonomy relies on the detachment between public administration and the political system, the governance perspective argues for a balance between management autonomy and democratic order to provide institutional improvement and reforms (OLSEN, 2009). The concept of governance contends that institutional reforms should promote improvements not only in management mechanisms, but also to enhance democratic legitimacy. Governance means not only how institutions promote their management capacity, but also how they are 
accountable to citizens, adapt and learn from their own mistakes, and promote values that spread development and solidarity (MARCH \& OLSEN, 1995).

More than a closed perspective of a theory, this governance approach is a strategy - it is a way to improve public services and public policies institutionally. Essentially, the governance strategy seeks to align the actions of public organizations with the interests of society and make it more capable of achieving its mission (CAPANO et al., 2014). The governance strategy means conducting a process of institutional change that recognizes bureaucracy's role in formulating and implementing public policies and services, which is associated with a political system that ensures greater openness and connection with society.

Institutional mechanisms of governance focus directly on public policies and public services, depending on building administrative capacities, relational capacities, and analytical capacities. These capabilities interact so that public policy formulation and implementation occur in complex systems of multiple streams that encompass global, regional, and local arenas.

There are three elements (acting as tools) to a governance strategy. First, it improves transparency and accountability to achieve compliance. Second, it creates channels of participation and networks with society. Third, it builds mechanisms of political coordination in multilevel organizations. Working together, these tools buttress the legitimacy of public policies and government's action in society (PETERS \& PIERRE, 2016; FiLGUEIRAS, 2018).

Governance embraces not only the development of economic aspects but also criteria that seek to qualify its management mechanisms These qualities are noneconomic factors such as subjective happiness (FREY \& STUTZER, 2000), citizen support for government (ANDERSON \& TVERDOVA, 2003), and democratic stability (MUNGIUPIPPIDI, 2006). The governance perspective recognizes the qualitative aspect of government in light of public policies and services supply that recognizes the value of equity as a founding principle of the political regime and a fundamental public value of the administration (ROTHSTEIN \& TEORELL, 2008; FILGUEIRAS, 2018).

Public policies aimed at implementing SDGs occur in complex governance contexts. First, this happens because SDGs are formulated in a global arena, with different actors and by consensus. Second, policy implementation for SDGs involves translating objectives into targeted local policies coherent with the global development perspective. Third, implementation of these policies will be evaluated in local and global arenas, broadening the 
multiple streams of decision making and possibility of institutional learning. Fourth, governance conditions depend on the political and institutional environment to create support for the policies implemented.

With this in mind, the next section looks at analyzing the 2030 Agenda and the challenges of its implementation in Brazil.

\section{Governance conditions for implementing Brazil's SDGs: a policy capacity approach}

Overall, this paper aims to discuss governance conditions for implementing policies targeting the UN SDGs in Brazil. We argue that the SDGs provide a rich set of interconnected policies to address key aspects of the governance debate, such as the capacities' behavior in a complex policy-implementation context - for example, the contingency of policy areas or types of policies; the association between administrative operational and relational capacities; and the dynamics of governance tools.

Recent studies agree that the 2030 Agenda requires effective strategies (from governments around the world) for achieving policy integration and coherence. The 17 SDGs should act in an integrated, indivisible, and aggregated way (NILSSON, 2017). That is, the 2030 Agenda demands that public policies present coherence and integration to achieve a systemic development that balances the economic, social, and environmental spheres (European COMMission, 2015; GeOrgeson \& MASLin, 2018; HowletT \& SAGUIN, 2018). In this direction, two elements are essential for implementing policies to achieve the SDGs. First, creating governance mechanisms that ensure collaboration. Second, collaboration is essential to promote policy integration. These two elements depend on how actors can translate the goals set in the global arena to the local arena and promote policy collaboration and integration to increase policy coherence. 
Figure 1 - A model of collaborative governance

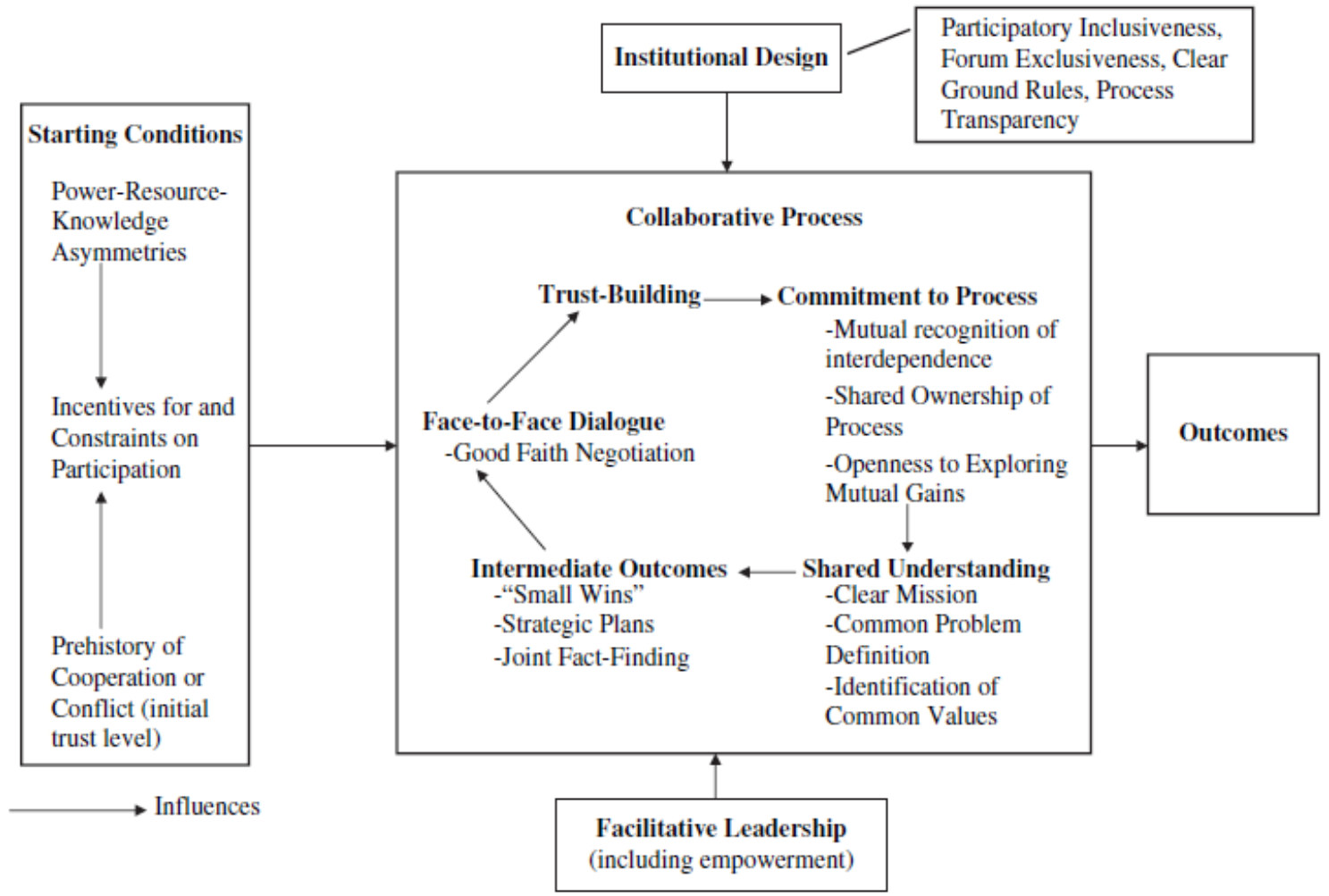

Source: Ansell and Gash (2007, p. 8).

Ansell and Gash (2007) advanced the debate on governance conditions, proposing a more comprehensive analytical framework to explain the stages of the collaborative process (Figure 1). Based on a meta-analytic study of 137 cases of collaborative governance, the authors sustain that process models of collaboration result from a combination of (1) starting conditions - that involve accumulated capacities, incentives for participation, and a history of cooperation; (2) institutional design - that is, ground rules of collaboration; and (3) facilitative leadership. A positive arrangement of these aspects produces collaborative governance.

Howlett and Saguin (2018) propose an operational definition that advances the traditional dichotomy of horizontal-vertical integration. It sets policy integration as "the process of reconciling incoherent policy goals and inconsistent policy instruments and pointing them towards more congruent policies" (HowLETT \& SAGUIN, 2018, p. 3). Starting from the comprehension of forms of policy integration as types of strategies for policy coherence, which is the stage in which policies reinforce themselves mutually in the same directions (PETERS, 2015), the authors provide a typology of the policy integration level based on the degree of goals' and instruments' consistency: that is, harmonizing, mainstreaming, coordinating, and institutionalizing policies. Each form of policy integration holds different 
levels of consistency among goals and tools and demands a specific type of strategy and mechanisms to reach policy coherence. Table 1 synthesizes the imbricated model of levels of policy integration; it appears that the SDGs would demand the highest level of integration during the institutionalization stage.

Table 1 - Relationship of coherence, strategies, and critical governance mechanisms according to the forms of integration

\begin{tabular}{|c|c|c|c|}
\hline $\begin{array}{l}\text { Forms of } \\
\text { integration }\end{array}$ & $\begin{array}{c}\text { Relationship } \\
\text { of } \\
\text { consistency }\end{array}$ & Strategy & Critical governance mechanism \\
\hline Harmonizing & $\begin{array}{l}\text { Inconsistent } \\
\text { goals and } \\
\text { tools }\end{array}$ & Standardization & $\begin{array}{l}\text { Organizational leadership with a } \\
\text { central position within the } \\
\text { government, with resources and } \\
\text { legitimacy to integrate actors to } \\
\text { work together }\end{array}$ \\
\hline Mainstreaming & $\begin{array}{l}\text { Consistent } \\
\text { tools and } \\
\text { inconsistent } \\
\text { objectives }\end{array}$ & Regulation & $\begin{array}{l}\text { Modifying the framework of } \\
\text { organizational planning, } \\
\text { regulations, and procedures }\end{array}$ \\
\hline Coordinating & $\begin{array}{l}\text { Inconsistent } \\
\text { tools and } \\
\text { consistent } \\
\text { objectives }\end{array}$ & Query and bargain & $\begin{array}{l}\text { Transforming the actors' political } \\
\text { positions in collective action results }\end{array}$ \\
\hline Institutionalizing & $\begin{array}{l}\text { Instruments } \\
\text { and } \\
\text { objectives } \\
\text { consistent }\end{array}$ & $\begin{array}{l}\text { Creation of } \\
\text { permanent roles to } \\
\text { deal with cross- } \\
\text { cutting issues }\end{array}$ & $\begin{array}{l}\text { Cooperating voluntarily through a } \\
\text { shared governance scheme }\end{array}$ \\
\hline
\end{tabular}

Source: Adapted from Howllet and Saguin (2018).

Acknowledging the increasing complexity of public problems and required specialization for policy making, more recent governance literature highlights that certain challenges of the SDGs' Agenda magnitude cannot be faced easily by a sole organization. In turn, it requires state capacity for producing multiorganizational arrangements (AGRANOFF, 2013) and for operating in a "complex process through which a plurality of social and political actors with divergent interests interact to formulate, promote and achieve common goals through the mobilization of interests, exchanging and implementing a series of ideas, rules and resources" (TORFING et al., 2012, p. 14). In other words, it demands high levels of policy capacities.

The analysis of governance, as well as implementation and bureaucracy studies, have advanced to the conception of policy capacity. In fact, the concept of policy capacity seeks to understand the role of bureaucracies in implementation by assembling 
perspectives based on the interaction between individuals and organizations. In Howlett and Ramesh's work (2014), they discuss critical interfaces between policy capacity for governance and states. Starting from a definition that conceives "policy capacity as the set of skills and resources - or competences and capabilities - necessary to perform policy functions" (Wu et al., 2015, p. 2), the authors argue that policy capacity in its three dimensions (analytical, managerial, and political) are crucial for governance success.

Analytical capacity consists of the state's accumulative skills and resources to produce evidence for effective policy formulation, while managerial capacity allows the state to manage its resources effectively, and political capacities translate the state's ability to maneuver and negotiate ideas, programs, and plans with society and other policy stakeholders (HowletT \& RAMESH, 2014). From that theory, the concept of policy capacity coalesces the necessary skills and resources for policy implementation, while factoring individual, organizational, and systemic dimensions. These dimensions and levels of capacity bring together predictors of policy results (WU et al., 2015). It incorporates both dimensions: the collective action of state bureaucracies and political elements of legitimacy built in the state's interaction with society (MOORE, 1995).

Acknowledging the distinct dimensions of policy capacities as conditions for governance, this investigation tackles the following questions: What are the policy capacity constraints and governance arrangements to enable institutional conditions for the implementation of development policies? How are governance tools structured for the process of implementing public policies in Brazil?

\section{Methodology}

This investigation was carried out in three main phases. The first relied on the analysis of official documents produced by the Brazilian federal government after committing to the 2030 Agenda. The National Voluntary Report on the Sustainable Development Goals (2017) and CNODS' Plan of Action (2017) were the main sources.

The second phase entailed a set of semi-structured interviews with government representatives of CNODS. Representatives of the Secretariat of Government of the Presidency of the Republic (SEGOV); Presidency of the Republic Staff; Ministry of Planning, Development and Management (MP); Ministry of Environment (MMA), and 
Ministry of Social Development (MDS) were interviewed. ${ }^{1}$ Actors from the permanent technical advisory bodies of the Commission, the Brazilian Institute of Geography and Statistics (IBGE) and the Institute of Applied Economic Research (IPEA) also were interviewed.

In addition, the representative of the Abrinq Foundation for the Rights of Children and Adolescents (Abrinq Foundation) - one of the representatives of nonprofit entities in the Commission - was interviewed. There also were interviews with representatives of the United Nations Development Program (UNDP) that supports the Brazilian government in integrating the SDGs in its development actions.

In the process of conducting interviews, two new state actors were mentioned as relevant in the process of implementing the 2030 Agenda: the Federal Audit Office (TCU) and the National School of Public Administration (ENAP). As a result, these two actors were interviewed to expand the understanding of the challenges and critical capabilities surrounding the implementation.

Thus, 12 organizations were consulted in 12 interviews conducted from June to August 2018. The individuals selected to be interviewed in each organization were based on their participation on the CNDOS meetings and their strategic role in implementing the 2030 Agenda in the agency. Regarding interviews with the key actors in implementing the 2030 Agenda, content analysis was used. The analytical categories were defined after the interviews and were articulated via discussion of governance and policy capacity literature.

The investigation's third phase entails analyses of survey data produced by research carried out by ENAP (2018) on "Capacities of the Federal Public Administration for the Production of Public Policies." ENAP's survey was sent to a random sample of the 101,000 federal civil servants working in the agencies of the Federal Public Administration from October to December 2017. The sample consisted of 6,055 individuals distributed across 24 agencies. The response rate reached 30\%, which corresponds to 2,000 individuals. $^{2}$

\footnotetext{
${ }^{1}$ The Ministry of Foreign Affairs (MRE) was the only governmental member of CNODS that could not be interviewed, because it was impossible to find a common agenda for interviews during the period of the study.

${ }^{2}$ More information on civil service characterization, as well as on the process of sampling and data collection, can be found in ENAP (2018), available at https://www.enap.gov.br/index.php/pt/pesquisas/capacidades-estatais.
}

REVISTA DO SERVIÇO PÚBLICO | Brasília 71 (special) 38 - 77 Oct. 2020 
This dataset was analyzed based on descriptive statistics, considering measures for central tendency, having as a unit of analysis the agencies of the Federal Public Administration existing in March 2017, which is when we generated the database used for the sampling process. This yielded information to discern critical capabilities held by each agency, providing a more accurate picture of the present and absent dimensions necessary to implement public policies associated with the SDGs. Annex I lists the organizations consulted.

Simple correspondence analysis - a statistical technique that provides a graphical representation of cross-tabulations - was also applied to examine patterns of relationships and use of informational resources. Cross-tabulations arise whenever it is possible to place events into two or more different sets of categories. Furthermore, this technique provides a means of graphically representing the structure of cross-tabulations, to shed light on underlying mechanisms. To confirm with reasonable certainty the distribution from sample to sample, the usual method of answering such questions is Pearson's chisquare test for independence; it tests whether a cross-tab deviates significantly from one in which rows and columns are independent (YeLLAND, 2010).

\section{Findings}

Policy capacity and governance analysis tend to emphasize government as an organized and unique entity. However, empirical research shows how organizations are different and shows variations in their capacity as well as the constitution of their governance mechanisms. Governments are both islands of excellence and organizations with many governance failures (BERSCH et al., 2016).

The main finding of this research is that analytical and relational capacities for implementing SDGs in Brazil are unevenly distributed among federal agencies. Although there are islands of excellence, most agencies have weak conditions to meet the 2030 Agenda's high demands. What explains the success or failure of policy coherence implemented by federal government agencies with the 2030 Agenda is the political leadership of the 2030 Agenda process and the relational aspect of policy work performed by the bureaucracy.

The findings will be presented as follows. First, we address the interviews to identify governance failures in implementing the 2030 Agenda in Brazil. Second, we 
show the variations in capacities among federal government agencies and how they mobilize their policy capacities in different ways.

\subsection{What are the critical conditions for SDGs' implementation in Brazil according to federal government representatives?}

Official documents from CNODS reveal that the Commission identifies three main challenges for creating governance arrangements and reaching sustainable development in 2030 (BRAZIL, 2017). First, these documents refer to the need for developing data and statistics that allow decision making and adaptation in public policies, as well as improvements in the country's monitoring and evaluation systems (BRAZIL, 2017). A second dimension relates to the importance of developing coordination mechanisms among the three federal branches. It is crucial to develop institutional capacities of the state and municipal governments, too, to fight disparities among subnational entities (BRAZIL, 2017). Third, mobilizing financial resources and strengthening partnerships and networks with civil society also are identified as important to this agenda that transcends state borders (BRAZIL, 2017).

Interviews confirmed some of these aspects, although additional considerations were raised by the Agenda conductors as being vital to its success. After scrutinizing critical capacities, the interviews detailed specificities along different dimensions.

Regarding the analytical dimension, interviews highlighted the following challenges for the Brazilian federal agencies to perform data collection and analysis at the level required by the SDG Agenda: (1) slowness in generating indicators; (2) failure to monitor actions; (3) lack of a long-term planning culture; (4) lack of clarity in defining priorities and goals; (5) lack of a system to evaluate performance; and (6) deficiency in managing integrated information.

As described by an interviewee, to integrate and define goals and indicators, this process "depends on information in order to analyze, and this information does not exist. Therefore, we cannot say that this information does not exist. It exists, however it is not organized." Another actor (interviewee) underscored, "We need to have statistics. Many of the proposed things depend on initiatives to be funded ... a lot of upgrading of the information system." Therefore, regarding analytical capacity at the federal agencies level, the general perception from interviewees is that higher levels are required to reach 
the integrative standard demanded by the SDGs' Agenda.

Two other dimensions of capacity were pointed out by interviewees. Both are understood in this investigation as subtypes of a broader relational dimension. Internal coordination is conceived in $\mathrm{Wu}$ et al. (2016)'s model as part of the administrative dimension. It relates to the resources and skills that increase the internal coherence of state action, involving intersectoral and interfederative coordination. Therefore, they enhance policy agency inside the executive branch. Political capacity, as mentioned before, entails the ability to mobilize stakeholders outside the state membrane, such as civil society, economic agents, citizens, and affected populations.

Concerning the internal coordination dimension, interviewees reported concerns with the lack of interactions between the Ministries and the low level of openness to this Agenda. Apparently, capillarity of the SDGs' Agenda varies widely among ministries. According to one interviewee: "Some ministries pay more attention; others less [to the SDGs' Agenda]." Also, "almost all ministries are very closed communities ... What happens is that some ministries have a more internationalized agenda - as, for instance, environment, science and technology, and health. Ministries with more people traveling are more familiar with global discussions."

In short, the interviews point to a degree of self-centeredness surrounding the federal government's organization. So, high levels of bureaucratic insulation are perceived as a relevant hindrance to SDGs' Agenda coordination.

Furthermore, as one of the interviewees describes:

So another complicating factor, in addition to this issue of the planning model not having established priorities, so that the line agencies can act in an integrated way at the federal level, [is] there is also the difficulty of integrating the national entity with subnational ones in the implementation of policies. So, these are issues. But it is not the lack of an installed capacity; I think it is much more issues to be solved on management models, [a] planning model.

According to interviewees, the challenges related to relational capacity are both in the internal coordination subdimension (at the federal level intersectorally and interfederative), as well as in the political subdimension related to state interaction with non-state stakeholders.

Thus, regarding the relational capacities, they highlighted the following challenges: (1) ministries' isolation; (2) low articulation capacity among sectors and among levels of government; (3) lack of articulation between the center of government and line agencies; (4) lack of intersectoral trust; (5) low communication capacity; (6) lack 
of a matrix work culture; (7) disputes among and intra-agencies; (8) lack of internationalization of public policies of executive agencies.

The interviews raised relevant findings concerning other conditions for SDGs' governance in Brazil, including low levels of agencies' involvement and lack of empowered leadership. Interviews report that SDGs, despite being allocated formally at the Presidency, are not today a center-of-government agenda. Although the National Commission is placed under the Presidency, the interviews underlined that this agency is not sufficiently empowered to carry out the SDGs' Agenda. Interviews suggest that more autonomy of leadership is required. Most interviewees identify the Casa Civil (Chief of Staff Office) as the entity that should lead the process.

In addition, interviewees highlight the relevance of institutional changes as well. As stated by one interviewee:

\begin{abstract}
There is no police coordination, unlike other countries that have created ... There are countries that have seized the opportunity of the 2030 Agenda for institutional change in their power structures, in their governance structures, in order to, to some extent, favor some issues of the SDGs, which is not the case in Brazil. There are at most isolated efforts. There is little capacity to change the course of politics.
\end{abstract}

In addition to coordination structure, strong fiscal structure and political stability were also pointed out as determining conditions related to the institutional environment.

From this, we concluded that federal government discourse and the perception of the Agenda's current conductors in Brazil confirm Ansell and Gash (2007)'s model pointing out that capacities, institutional design, and leadership are the primary conditions for building a collaborative governance process to the SDGs implementation in Brazil (Figure 2).

Figure 2 - Brazilian governance conditions for sustainable development goals' (Sdgs') implementation

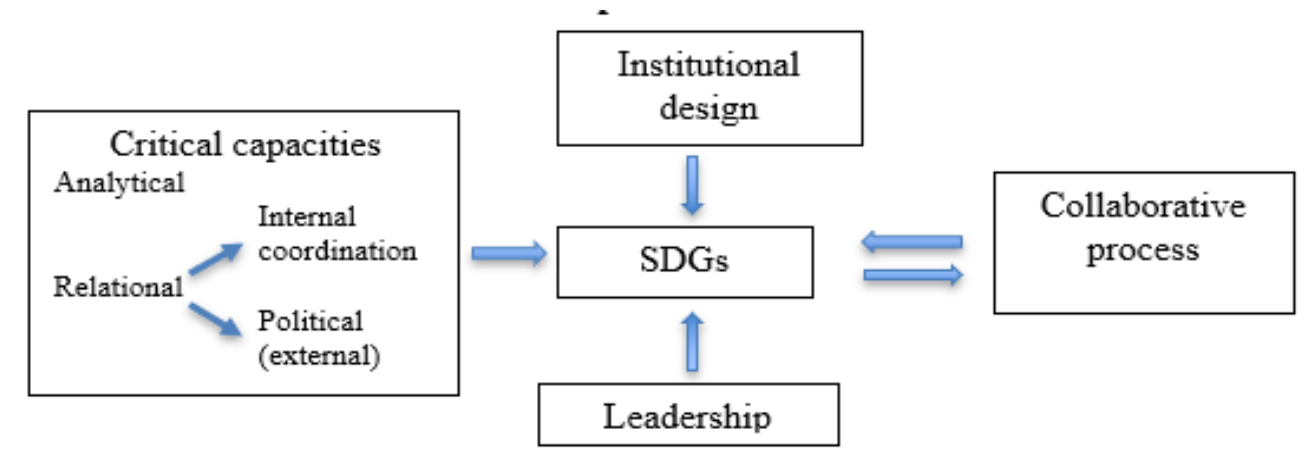

Source: Adapted from Ansell and Gash (2007). 
The following sections examine survey data that provide a diagnosis of the levels of these conditions in Brazil's federal agencies to identity the stage of the collaborative process or form (HowletT \& SAGUIN, 2018) found in the country for the SDGs' implementation.

\subsection{Diagnosis of policy capacity conditions and governance arrangements for SDGs' implementation}

\subsubsection{Levels of capacity}

Next, this section pursues the question: "Do all Brazilian federal agencies have the organizational capacity to participate in a meaningful way in implementing the SDGs?" To find out, data regarding analytical, coordination, and political capacities are examined.

\section{Analytical capacity}

Table 2 shows that the distribution of analytical capacities varies among Brazilian federal agencies and that they are not high in general. "To define indicators and methodologies to evaluate and monitor the public policy" translates the substantial level of analytical capacity necessary for SDGs' implementation. On a scale of 1 to 10 , in which 1 was very difficult and 10 very easy, civil servants were asked to inform on which level they perform that activity in their policy work. The data indicates that it was not an easy task for them to perform.

Table 2 - Average frequency of civil service's ability to define indicators and methodologies to evaluate and monitor public policy

\begin{tabular}{c|c|c|c|c|c}
\hline Agency & Averages & Agency & Averages & Agency & Averages \\
\hline AGU & 4.71 & MF & 4.79 & MME & 5.18 \\
\hline $\begin{array}{c}\text { Chief of } \\
\text { Staff Office }\end{array}$ & 6.55 & MDIC & 5.63 & MDS & 5.61 \\
\hline GSI & 5.21 & MI & 5.47 & ME & 4.88 \\
\hline MTPA & 4.55 & MJ & 5.51 & MMA & 5.53 \\
\hline MCTI & 5.59 & MS & 5.65 & MP & 5.63 \\
\hline MINC & 5.52 & CGU & 5.29 & MT & 5.10 \\
\hline MD & 6.02 & MCid & 5.56 & MTUR & 5.72 \\
\hline MEC & 5.90 & MRE & 4.78 & MDH & 6.55 \\
\hline MTPA & 5.49 & $\begin{array}{c}\text { General } \\
\text { Gov. PR }\end{array}$ & 6.07 & $\begin{array}{c}\text { General Sec. } \\
\text { PR }\end{array}$ & 5.10 \\
\hline
\end{tabular}

Source: ENAP, Research on Challenges and Conditions to SDGs' Agenda Implementation in Brazilian Federal Public Administration, 2018. 
As Table 3 shows, many sources of information that could contribute to the decision-making process are not used on a recurring basis. Experts' and international bodies' opinions, as well as the recommendations and/or resolutions of conferences and public policy councils are among the less used. All combined, these exceed $70 \%$ of nonuse. When accessed on a daily basis, those with the highest employment are information from traditional media (16\%) and social media or social networks (13\%), followed by recommendations and determinations of audit bodies and legal opinions and decisions, each with $12 \%$. Therefore, in general, while traditional analytical work such as scientific or technical knowledge do not seem to be relevant in policy making, endogenous information produced within the state and media in general seem to be the most influential sources.

Table 3 - Information resources

\begin{tabular}{|c|c|c|c|c|c|c|c|c|c|c|c|c|c|c|}
\hline \multirow{2}{*}{ Type of resource } & \multicolumn{2}{|c|}{ Average } & \multicolumn{2}{|c|}{ Never } & \multicolumn{2}{|c|}{$\begin{array}{l}\text { Sometimes } \\
\text { in the year }\end{array}$} & \multicolumn{2}{|c|}{$\begin{array}{l}\text { Sometimes } \\
\text { in the } \\
\text { month }\end{array}$} & \multicolumn{2}{|c|}{$\begin{array}{l}\text { Every } \\
\text { week }\end{array}$} & \multicolumn{2}{|c|}{ Every day } & \multirow{2}{*}{ Answers } & \multirow{2}{*}{ Missing } \\
\hline & $\mathbf{N}$ & $\%$ & $\mathbf{N}$ & $\%$ & $\mathbf{N}$ & $\%$ & $\mathbf{N}$ & $\%$ & $\mathbf{N}$ & $\%$ & QTD & $\%$ & & \\
\hline $\begin{array}{l}\text { Statistical data or } \\
\text { surveys }\end{array}$ & 2 & 31 & 512 & 31 & 523 & 31 & 318 & 19 & 205 & 12 & 106 & 6 & 1,664 & 336 \\
\hline $\begin{array}{l}\text { Monitoring and } \\
\text { evaluation data of } \\
\text { public policy } \\
(\mathrm{PP}) \text {. }\end{array}$ & 2 & 33 & 457 & 27 & 558 & 33 & 356 & 21 & 194 & 12 & 120 & 7 & 1,685 & 315 \\
\hline $\begin{array}{l}\text { Legal opinions } \\
\text { and judicial } \\
\text { decisions }\end{array}$ & 2 & 28 & 394 & 23 & 484 & 28 & 397 & 23 & 244 & 14 & 211 & 12 & 1,730 & 270 \\
\hline $\begin{array}{l}\text { Recommendation } \\
\mathrm{s} \text { and } \\
\text { determinations of } \\
\text { the audit bodies }\end{array}$ & 2 & 36 & 310 & 18 & 626 & 36 & 365 & 21 & 224 & 13 & 205 & 12 & 1,730 & 270 \\
\hline $\begin{array}{l}\text { Recommendation } \\
\text { s from } \\
\text { participatory } \\
\text { instances (e.g., PP } \\
\text { councils or } \\
\text { conferences) } \\
\end{array}$ & 2 & 37 & 570 & 35 & 609 & 37 & 254 & 16 & 118 & 7 & 80 & 5 & 1,631 & 369 \\
\hline $\begin{array}{l}\text { Expert opinion } \\
\text { and international } \\
\text { organizations } \\
\end{array}$ & 1 & 39 & 642 & 39 & 544 & 33 & 254 & 16 & 115 & 7 & 74 & 5 & 1,629 & 371 \\
\hline $\begin{array}{l}\text { Experiences or } \\
\text { opinions of PP } \\
\text { beneficiaries }\end{array}$ & 2 & 33 & 538 & 33 & 577 & 35 & 294 & 18 & 136 & 8 & 90 & 6 & 1,635 & 365 \\
\hline $\begin{array}{l}\text { Information } \\
\text { generated by } \\
\text { interest groups }\end{array}$ & 1 & 36 & 585 & 36 & 544 & 33 & 299 & 18 & 141 & 9 & 64 & 4 & 1,633 & 367 \\
\hline $\begin{array}{l}\text { Social media or } \\
\text { social networks }\end{array}$ & 1 & 38 & 624 & 38 & 384 & 23 & 254 & 15 & 184 & 11 & 215 & 13 & 1,661 & 339 \\
\hline Traditional media & 1 & 28 & 473 & 28 & 428 & 26 & 293 & 18 & 204 & 12 & 276 & 16 & 1,674 & 326 \\
\hline
\end{tabular}

Source: ENAP, Research on Challenges and Conditions to SDGs' Agenda Implementation in Brazilian Federal Public Administration, 2018. 
The general pattern depicted here can be found at some level in different agencies, to varying degrees. Figure 3 shows the results of correspondence analysis that illustrates each agency pattern of use of these three sets of data resources. ${ }^{3}$ Different interpretations can emerge from that analysis. Data shows that few agencies have a high level of use of traditional analytical data, although "islands of excellence" are identifiable, such as the MDS (Ministry of Social Development) and the MEC (Ministry of Education). Legal and audit sources influence most agencies, revealing a specificity of the Brazilian context. And some agencies practically do not use any of these informational sources, such as the Ministry of Defense (MD) and Ministry of Finance (MF).

\section{Figure 3 - Use of informational resources, by agency}

\section{Traditional analytical data}
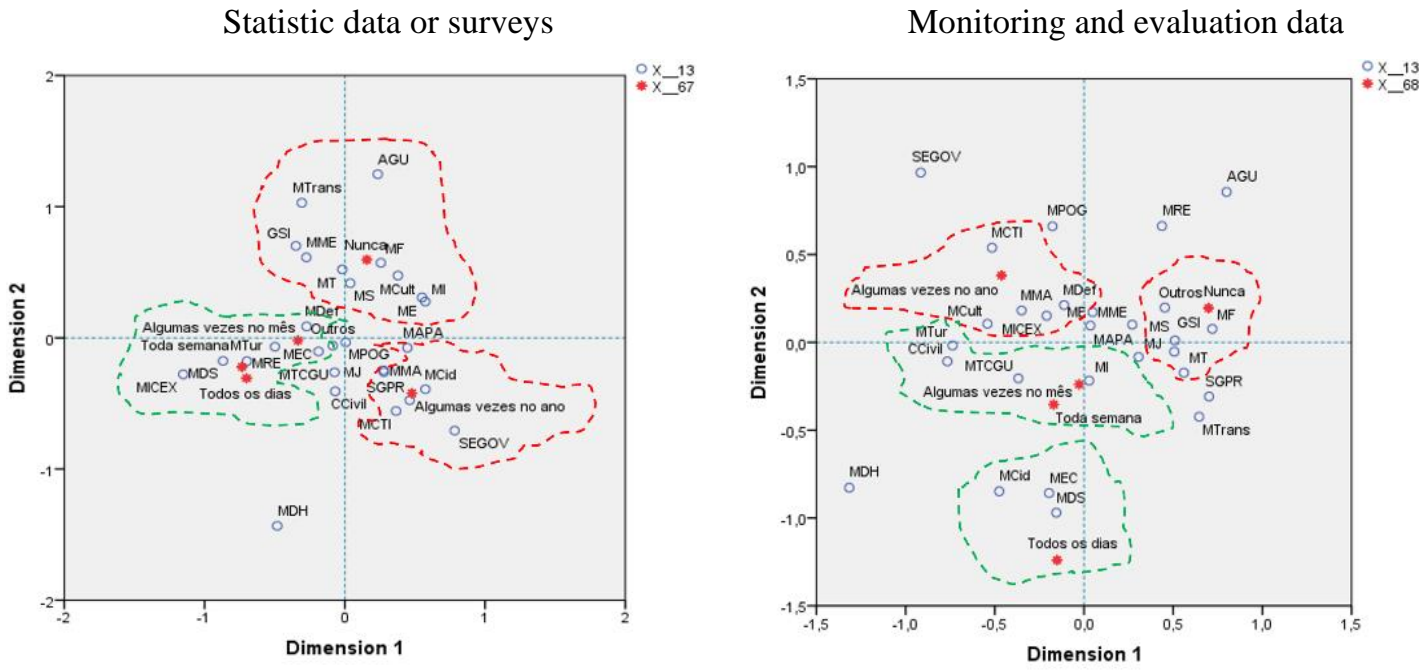

Legal and audit sources

Legal recommendations and decisions

Audit recommendations and regulations
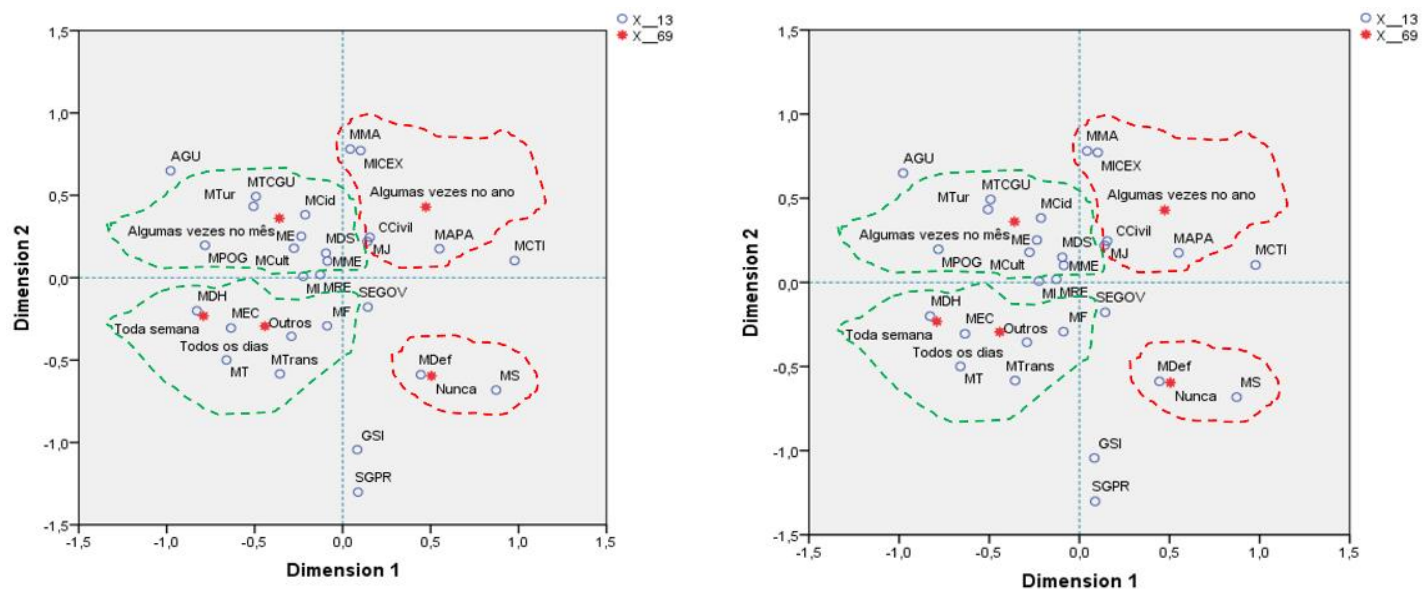

${ }^{3}$ All correspondence analyses were significant (at a level of $1 \%$ or $5 \%$ ). 
Social media or social networks

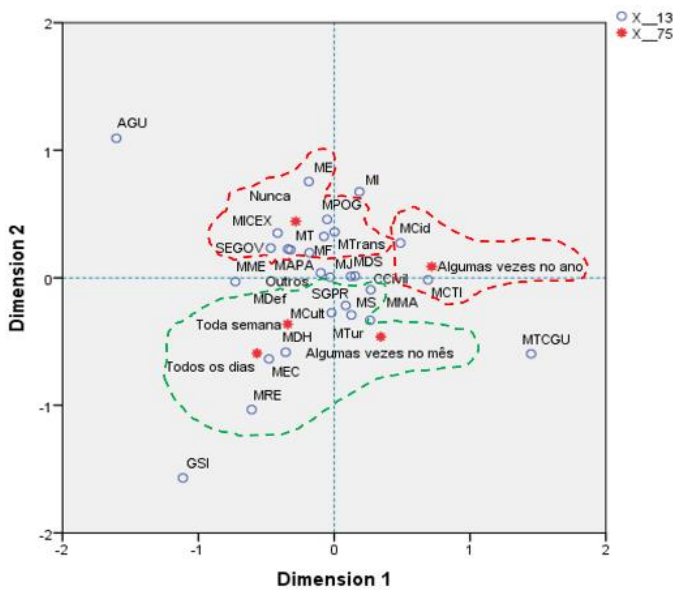

Traditional media

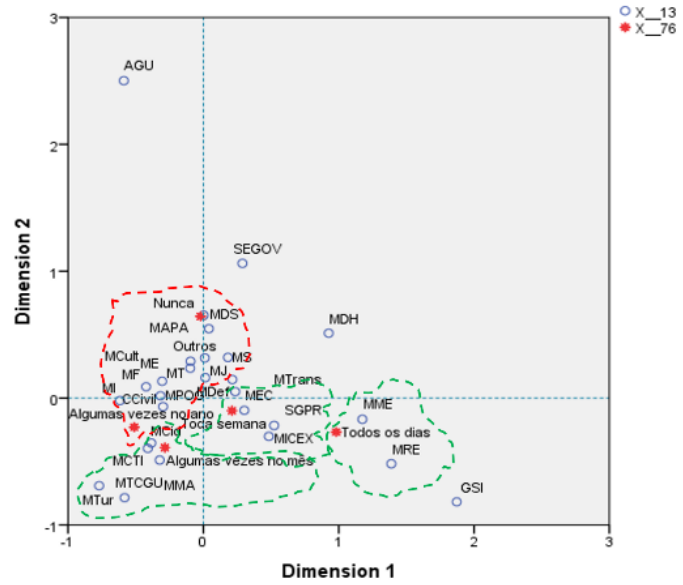

Source: Authors' elaboration and Macedo et al. (2019).

\section{Relational capacity}

On the relational context, respondents were questioned about interactions with other agencies and entities in their work. According to Figure 4, 57\% of respondents stated that the public policy are in which they work is implemented in collaboration with other ministries of the Federal Government. That is, according to the respondents' general perception, most of the public policies implemented by the federal public administration are inherently intersectoral.

Among those surveyed, $42 \%$ answered that they also implement public policy in conjunction with states and municipalities, placing the interfederative component of policy implementation second in comparison to different possible partners.

\section{Figure 4 - With whom public policy is implemented}

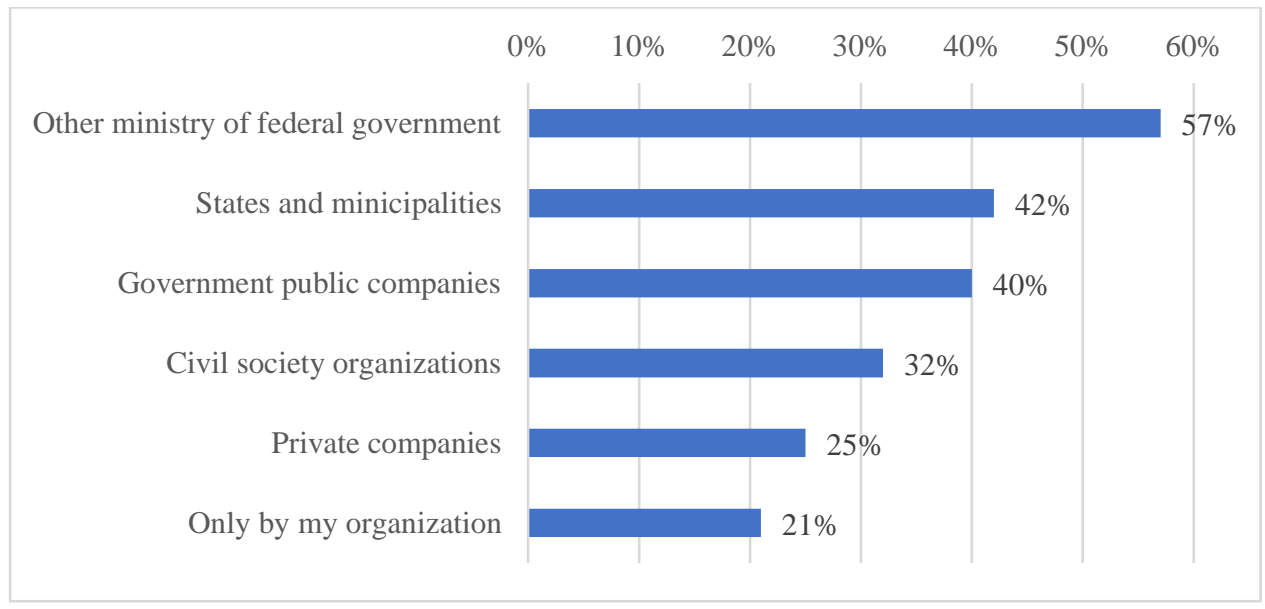

Source: ENAP, Research on Challenges and Conditions to SDGs'Agenda Implementation in Brazilian Federal Public Administration, 2018. 
Thus, $40 \%$ of respondents said they worked in association with the Federal Government's public authorities and public companies in implementing public policy in their work arena. About one-third (32\%) of the identified public policies are implemented in a collaborative way with civil society organizations, such as associations, foundations, and cooperatives. Only a quarter of respondents (25\%) point to private companies as partners, and about one-fifth (21\%) say public policies are implemented only by the responsible agency.

\section{Internal coordination}

Along with Figure 4, Figure 5 confirms that a significant portion of agencies seem to work in isolation from other federal agencies. And a greater number of agencies do not collaborate with local government. So, intersectoral and interfederative capacities are unevenly carried by different agencies. Red boundaries indicate the absence or lower levels and green corresponds to moderate and higher levels of interaction with other agencies.

Figure 5 - Frequency of Interactions with other actors and organizations from the Executive Branch

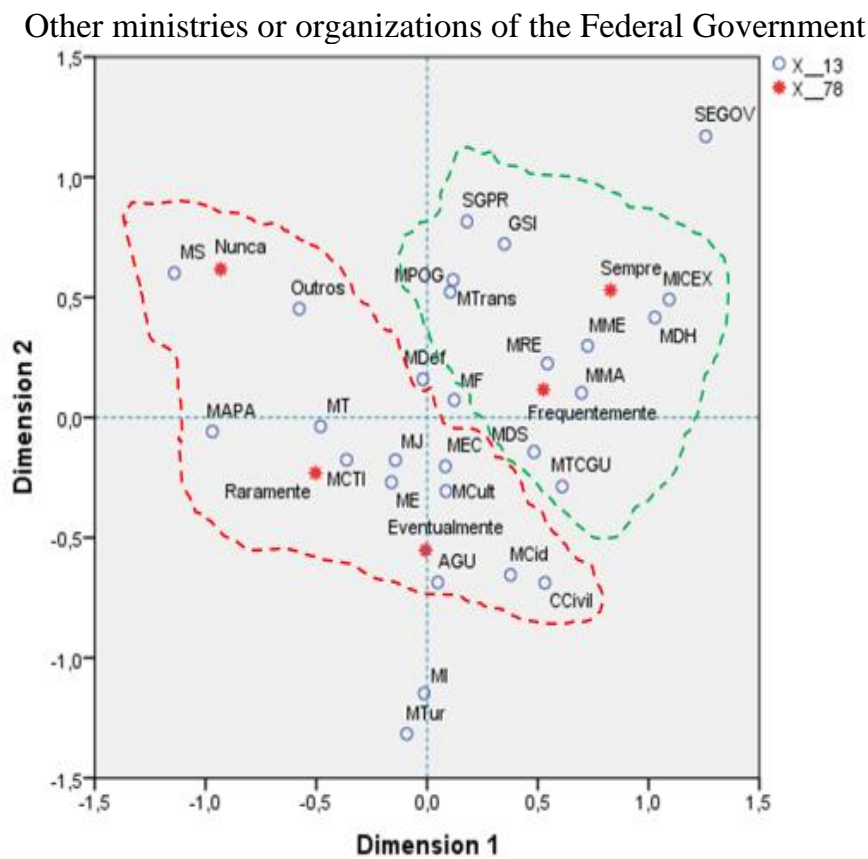



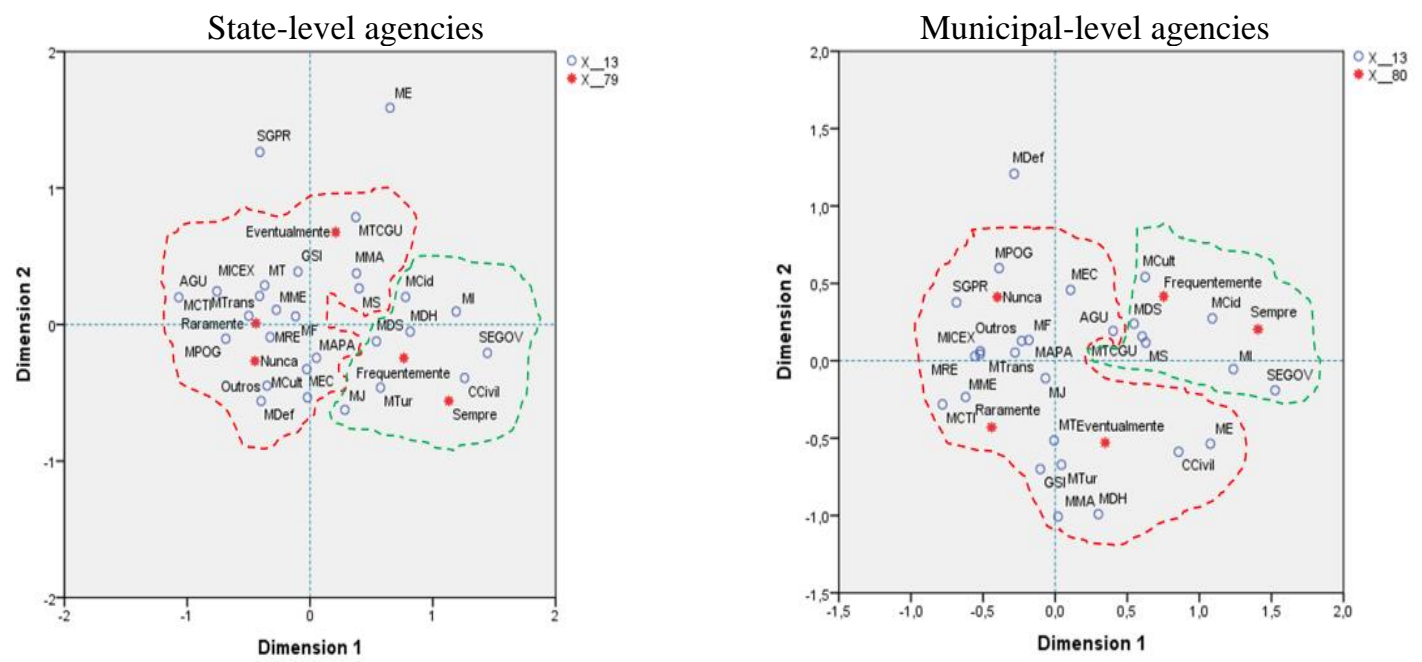

Source: Authors' elaboration.

\section{Intersectoral / horizontal collaboration}

In cases where the interviewee stated that there was collaboration with other federal agencies or entities in implementing public policies, in which he or she acted, the interviewees' perception of their agreement or disagreement on six statements was surveyed, seeking to analyze the conditions for coordinated action between the different entities. Response options ranged from 1 to 10, on an increasing scale of agreement, on each of the items presented. Table 4 presents the data per agency.

Taking into account Howlett and Saguin (2018)'s model of forms of integration, this question aimed to measure levels of consistency of goals and tools between federal agencies. As for the item "existence of clarity of roles and responsibilities", the mean of the interviewees' average in the scale was of a position of 6.35 , with a maximum position of 7.26, and a lower position of 4.71. The heterogeneity of interviewees' perception was measured from across different agencies. If we consider that there are agencies that approach or distance themselves from the middle of the scale, this indicates a variation of results depending on the policy area.

Regarding the item "existence of joint rules that facilitate cooperation", there are agencies for which the average responses of interviewees tended toward the middle of the scale, clarifying the behavior of responses in the average of the previous category.

In the item "existence of an intergovernmental coordination instance", the average maximum perception of the interviewees on the scale was in the order of 9.00, with an average minimum position of 5.00. In general, the answers' behavior was positioned close 
to the middle of the scale, with an average of 6.64. The value of the maximum average points to the existence of some interviewees' clear perception that the collaborative implementation of its agencies with others is mediated by an instance responsible for coordinating this interaction among governments.

Regarding the item "usual availability of the database and information to other agencies," an affirmation that placed the agencies as facilitators of collaborations, through the provision of data and information, there are cases in which the perception is highly positive, as in MDH, MEC, MDS, and in the MD. However, among all categories, there are cases where the lowest mean perception was in this category. The trend toward the middle of the scale of responses, on average, points to the possibility of a lack of a systematic data and information culture, which is another challenge indicated by interviewees for implementing the 2030 Agenda.

Concerning the item "there is competition of agendas and resources between my agency and other agencies," some agencies tended to strongly disagree with this assertion-yet there were others who strongly agreed, on average, to perceive competition. The existence of competition distances the possibility of effective cooperation to implement policies, in addition to denouncing the supremacy of unilateral planning of agendas and the execution of resources, as already pointed out by some interviewees, who are active in the 2030 Agenda.

The results of the interviewees' perception, on average, of "resistance to cooperation on mainstream issues" points to a perception that, when the topic is shown de facto as a co-petitioner, the willingness to collaborate seems to increase. This behavior of the responses, on average, shows the possibility of agencies' perception about the nature of policies they deal with, within their competence: there are policies that are "my agency," there are those that are of "other agencies," and there are those that require collaboration because they are not my exclusive competence. It should be emphasized that for this item there was a reversal on the response scale - that is, 1 corresponded to the lack of mainstream cooperation and 10 to total mainstream cooperation. Caution must be taken in interpreting Table 4. 
Table 4 - Average of interviewees' agreement on the collaborative implementation of public policies with other federal agencies or entities, per agency

\begin{tabular}{|c|c|c|c|c|c|c|}
\hline $\begin{array}{c}\text { Because } \\
\text { public policy } \\
\text { is } \\
\text { implemented } \\
\text { with other } \\
\text { federal } \\
\text { agencies or }\end{array}$ & $\begin{array}{l}\text { Existence of } \\
\text { clarity of } \\
\text { roles and } \\
\text { responsibiliti } \\
\text { es }\end{array}$ & $\begin{array}{l}\text { Existence of } \\
\text { an } \\
\text { intergovernme } \\
\text { ntal } \\
\text { coordination } \\
\text { agency }\end{array}$ & $\begin{array}{l}\text { Existence of } \\
\text { joint rules } \\
\text { facilitating } \\
\text { cooperation }\end{array}$ & $\begin{array}{c}\text { Usual } \\
\text { availability of } \\
\text { the database } \\
\text { and } \\
\text { information to } \\
\text { other bodies }\end{array}$ & $\begin{array}{l}\text { Existence of } \\
\text { competition of } \\
\text { intra-agency } \\
\text { and intra- } \\
\text { agency } \\
\text { agendas and } \\
\text { resources }\end{array}$ & $\begin{array}{c}\text { Existence of } \\
\text { resistance to } \\
\text { cooperation } \\
\text { on } \\
\text { mainstream } \\
\text { themes }\end{array}$ \\
\hline $\begin{array}{l}\text { much do you } \\
\text { agree with the } \\
\text { statements } \\
\text { below? }\end{array}$ & Average & Average & Average & Average & Average & Average \\
\hline $\mathrm{AGU}$ & 6.00 & 9.00 & 7.00 & 7.00 & 8.00 & 9.00 \\
\hline $\begin{array}{l}\text { Chief of Staff } \\
\text { Office }\end{array}$ & 5.55 & 5.61 & 5.20 & 5.63 & 6.52 & 5.92 \\
\hline GSI & 7.10 & 6.80 & 7.20 & 7.22 & 6.25 & 6.00 \\
\hline MAPA & 5.77 & 5.47 & 5.62 & 5.32 & 4.89 & 5.06 \\
\hline MCTI & 5.59 & 5.73 & 5.41 & 6.25 & 7.44 & 5.78 \\
\hline MINC & 6.17 & 5.19 & 5.15 & 5.50 & 5.38 & 5.61 \\
\hline MD & 6.94 & 8.00 & 7.69 & 7.47 & 5.84 & 4.52 \\
\hline MEC & 7.12 & 7.39 & 7.00 & 7.47 & 5.49 & 5.72 \\
\hline MF & 6.86 & 6.74 & 6.60 & 6.60 & 5.32 & 4.19 \\
\hline MDIC & 6.30 & 7.15 & 6.42 & 6.84 & 7.07 & 4.96 \\
\hline MI & 6.11 & 5.49 & 5.62 & 5.38 & 6.00 & 4.63 \\
\hline MJ & 6.89 & 7.60 & 7.09 & 6.95 & 4.92 & 4.95 \\
\hline MS & 5.93 & 5.63 & 5.51 & 6.25 & 5.63 & 4.41 \\
\hline MTFCGU & 6.14 & 6.53 & 6.48 & 6.64 & 6.05 & 5.26 \\
\hline MCid & 6.39 & 6.45 & 5.83 & 7.14 & 6.77 & 5.48 \\
\hline Itamaraty & 6.33 & 6.52 & 5.96 & 6.56 & 6.14 & 4.90 \\
\hline MME & 7.26 & 6.97 & 6.61 & 5.93 & 5.35 & 5.30 \\
\hline MDS & 6.86 & 7.31 & 7.16 & 7.43 & 5.73 & 6.22 \\
\hline ME & 4.71 & 5.00 & 5.92 & 6.31 & 6.64 & 5.00 \\
\hline MMA & 5.95 & 6.62 & 5.97 & 6.88 & 6.77 & 5.63 \\
\hline MP & 6.57 & 6.67 & 6.30 & 6.72 & 5.54 & 5.18 \\
\hline MT & 6.73 & 6.59 & 6.32 & 6.70 & 6.02 & 5.00 \\
\hline MTUR & 6.56 & 6.00 & 5.43 & 5.20 & 6.70 & 6.11 \\
\hline $\mathrm{MDH}$ & 6.00 & 7.33 & 5.33 & 8.00 & 6.17 & 7.43 \\
\hline MTPA & 7.13 & 6.79 & 7.05 & 6.62 & 5.26 & 4.63 \\
\hline Gov. Sec. PR & 6.07 & 7.00 & 5.15 & 7.00 & 5.00 & 6.00 \\
\hline
\end{tabular}




\begin{tabular}{|c|c|c|c|c|c|c|}
\hline $\begin{array}{c}\text { Because } \\
\text { public policy } \\
\text { is } \\
\text { implemented } \\
\text { with other } \\
\text { federal } \\
\text { agencies or }\end{array}$ & $\begin{array}{l}\text { Existence of } \\
\text { clarity of } \\
\text { roles and } \\
\text { responsibiliti } \\
\text { es }\end{array}$ & $\begin{array}{l}\text { Existence of } \\
\text { an } \\
\text { intergovernme } \\
\text { ntal } \\
\text { coordination } \\
\text { agency }\end{array}$ & $\begin{array}{l}\text { Existence of } \\
\text { joint rules } \\
\text { facilitating } \\
\text { cooperation }\end{array}$ & $\begin{array}{l}\text { Usual } \\
\text { availability of } \\
\text { the database } \\
\text { and } \\
\text { information to } \\
\text { other bodies }\end{array}$ & $\begin{array}{l}\text { Existence of } \\
\text { competition of } \\
\text { intra-agency } \\
\text { and intra- } \\
\text { agency } \\
\text { agendas and } \\
\text { resources }\end{array}$ & $\begin{array}{c}\text { Existence of } \\
\text { resistance to } \\
\text { cooperation } \\
\text { on } \\
\text { mainstream } \\
\text { themes }\end{array}$ \\
\hline $\begin{array}{l}\text { much do you } \\
\text { agree with the } \\
\text { statements } \\
\text { below? }\end{array}$ & Average & Average & Average & Average & Average & Average \\
\hline $\begin{array}{c}\text { General Sec. } \\
\text { PR }\end{array}$ & 6.13 & 7.43 & 5.43 & 5.33 & 8.40 & 5.20 \\
\hline Others & 6.65 & 7.02 & 6.10 & 6.31 & 6.05 & 5.45 \\
\hline Minimum & 4.71 & 5.00 & 5.15 & 5.20 & 4.89 & 4.19 \\
\hline Maximum & 7.26 & 9.00 & 7.69 & 8.00 & 8.40 & 9.00 \\
\hline Average & 6.35 & 6.64 & 6.16 & 6.52 & 6.12 & 5.48 \\
\hline
\end{tabular}

Source: ENAP, Research on Challenges and Conditions to SDGs' Agenda Implementation in Brazilian

Federal Public Administration, 2018.

Table 4 shows that, in general, there is a trend of responses toward the middle of the scale in the items related to consistency of goals and tools. However, heterogeneity also was found across agencies' results, suggesting that variation can be explained partially by policy areas. Nevertheless, when respondents were asked to inform whether they perceive competition or resistance when they have to work with other federal agencies, competition between agencies can be identified as one critical aspect in vertical collaboration.

\section{Interfederative / vertical collaboration}

Also, from a scale from 1 to 10, from "totally disagreeing" to "totally agreeing," survey respondents displayed a wide range of responses for four other items related to the conditions for collaboratively implementing federal public policies with states and municipalities. This question also acknowledges Howlett and Saguin's (2018) model of forms of integration to measure levels of goals' and tools' consistency in the interfederative relationship.

As for the item "existence of clarity of roles and responsibilities of each entity of the federation," there were cases in which interviewees' average perception was close to total disagreement, while others were close total agreement, according to Table 5. 
Next, we analyze the data that compares the answers of two items: "existence of tools and strategies that facilitate the cooperation of my agency with states and municipalities" and "current laws contribute to stimulating cooperation between federal government, states, and municipalities." We can see that there are agencies which, although on average they express strong agreement with the existence of clarity of roles and responsibilities among the entities, they strongly disagree on the existence of rules and tools that favor interfederative collaboration. That is, although the agencies know their role in collaboration, they do not have the necessary means to operate in collaboration, nor an integrated strategy that contemplates the direction of this type of implementation.

Finally, on the question of the "existence of resistance of states and municipalities to cooperate with the federal government," the responses' average behavior points to the involved entities' predisposition to collaborate, but this may be impeded because there are no clear rules establishing roles and responsibilities, as well as the lack of tools and legislation (laws) encouraging them to work collaboratively. Recall again that there is an inversion of the scale also in this item - that is, that option "1" (or red in Table 5) means the existence of total resistance of states and municipalities and "10" (or green in Table 5) means no resistance.

Table 5 - Average of interviewees' agreement on the collaborative implementation of public policies with states and municipalities, per agency

\begin{tabular}{l|c|c|c|c}
\hline $\begin{array}{l}\text { Given that public } \\
\text { policy is } \\
\text { implemented with } \\
\text { states and } \\
\text { municipalities, how } \\
\text { much do you agree } \\
\text { with these } \\
\text { statements? }\end{array}$ & $\begin{array}{l}\text { Existence of } \\
\text { clarity of roles and } \\
\text { responsibilities of } \\
\text { each entity of the } \\
\text { federation }\end{array}$ & $\begin{array}{l}\text { Existence of tools } \\
\text { and strategies that } \\
\text { facilitate the } \\
\text { cooperation of my } \\
\text { agency with states } \\
\text { and municipalities }\end{array}$ & $\begin{array}{l}\text { Current laws } \\
\text { contribute to } \\
\text { stimulating } \\
\text { cooperation } \\
\text { between federal } \\
\text { government, } \\
\text { states, and } \\
\text { municipalities }\end{array}$ & $\begin{array}{l}\text { Existence of } \\
\text { resistance of states } \\
\text { and municipalities } \\
\text { to cooperate with } \\
\text { the federal } \\
\text { government }\end{array}$ \\
\cline { 2 - 5 } & Average & Average & Average & Average \\
\hline AGU & 8.50 & 4.00 & 4.50 & 6.00 \\
\hline Chief of Staff Office & 6.70 & 5.72 & 5.69 & 5.54 \\
\hline GSI & 6.00 & 6.00 & 5.33 & 4.00 \\
\hline MAPA & 6.28 & 5.41 & 6.13 & 5.44 \\
\hline MCTI & 5.23 & 5.09 & 5.58 & 5.59 \\
\hline MINC & 6.86 & 5.88 & 5.81 & 5.00 \\
\hline MD & 7.38 & 6.31 & 5.08 \\
\hline
\end{tabular}




\begin{tabular}{|c|c|c|c|c|}
\hline $\begin{array}{l}\text { Given that public } \\
\text { policy is } \\
\text { implemented with } \\
\text { states and } \\
\text { municipalities, how } \\
\text { much do you agree } \\
\text { with these } \\
\text { statements? }\end{array}$ & $\begin{array}{l}\text { Existence of } \\
\text { clarity of roles and } \\
\text { responsibilities of } \\
\text { each entity of the } \\
\text { federation }\end{array}$ & $\begin{array}{l}\text { Existence of tools } \\
\text { and strategies that } \\
\text { facilitate the } \\
\text { cooperation of my } \\
\text { agency with states } \\
\text { and municipalities }\end{array}$ & $\begin{array}{l}\text { Current laws } \\
\text { contribute to } \\
\text { stimulating } \\
\text { cooperation } \\
\text { between federal } \\
\text { government, } \\
\text { states, and } \\
\text { municipalities }\end{array}$ & $\begin{array}{l}\text { Existence of } \\
\text { resistance of states } \\
\text { and municipalities } \\
\text { to cooperate with } \\
\text { the federal } \\
\text { government }\end{array}$ \\
\hline & Average & Average & Average & Average \\
\hline MEC & 7.28 & 7.56 & 7.19 & 5.67 \\
\hline MF & 6.89 & 7.03 & 5.97 & 5.94 \\
\hline MDIC & 6.42 & 6.89 & 5.85 & 5.20 \\
\hline MI & 6.92 & 6.25 & 5.66 & 5.25 \\
\hline MJ & 6.75 & 5.78 & 6.03 & 4.59 \\
\hline MS & 5.78 & 5.63 & 5.46 & 6.57 \\
\hline MTFCGU & 6.09 & 6.14 & 5.63 & 7.24 \\
\hline MCid & 6.83 & 4.91 & 4.97 & 5.32 \\
\hline Itamaraty & 7.70 & 7.11 & 6.20 & 5.80 \\
\hline MME & 3.29 & 3.14 & 3.50 & 3.83 \\
\hline MDS & 7.23 & 7.63 & 6.90 & 5.16 \\
\hline ME & 5.56 & 5.65 & 6.22 & 6.06 \\
\hline MMA & 5.90 & 5.36 & 5.28 & 5.26 \\
\hline MP & 5.65 & 4.53 & 5.75 & 6.16 \\
\hline MT & 6.52 & 5.48 & 6.29 & 5.10 \\
\hline MTUR & 7.00 & 6.94 & 7.00 & 5.19 \\
\hline $\mathrm{MDH}$ & 6.29 & 6.57 & 6.29 & 6.86 \\
\hline MTPA & 7.70 & 7.00 & 6.50 & 5.50 \\
\hline Gov. Sec. PR & 6.00 & 5.62 & 5.92 & 6.31 \\
\hline General Sec. PR & 7.00 & 4.50 & 4.00 & 1.50 \\
\hline Others & 6.43 & 5.50 & 5.47 & 5.10 \\
\hline Minimum & 3.29 & 3.14 & 3.50 & 1.50 \\
\hline Maximum & 8.50 & 7.63 & 7.19 & 7.24 \\
\hline Average & 6.51 & 5.84 & 5.71 & 5.37 \\
\hline
\end{tabular}

Source: ENAP, Research on Challenges and Conditions to SDGs' Agenda Implementation in Brazilian Federal Public Administration, 2018. 
In sum, goals and roles in vertical collaboration seem to be clearer than in horizontal collaboration, given that it is usually regulated in norms, law, or even in the Federal Constitution. Although the average of responses reached 6.51, that cannot be considered a high percentage. However, as with horizontal collaboration, fragilities also are found regarding the existence and performance of collaborative tools in many agencies.

Considering the challenges posed by interviewees in implementing the 2030 Agenda, the data point to the relevance of rethinking tools and rules to facilitate state performance, in an integrated way, in the three branches of government.

\section{Political capacity}

Figure 6 indicates how often federal agencies relate with the major external stakeholders, which enables us to deduce some conclusions regarding political capacities among federal ministries.

Most agencies stated they eventually, seldom, or never interact with the Legislative Branch. Only the Ministry of Human Rights (MHR) affirmed to always be in contact with legislative representatives, while the Ministry of Cities (MCid), SEGOV, and Institutional Security Officer (GSI) often interact with them.

Only some agencies inform that the always or frequently interact with civil society: the SEGOV, Ministry of Education (ME), Ministry of Culture (MCult), Ministry of Environment (MMA) and Chief of Staff Office (CCivil) always or often interact with this type of stakeholder.

For more institutionalized interactions with civil society within participatory instances, most agencies eventually, rarely, or never interact. Only the CCivil, SEGOV, Ministry of Social Development (MDS), and Ministry of Industry and Foreign Trade (MICEX) always or often relate to this same category. 


\section{Figure 6 - Frequency of interactions with external actors and organizations}

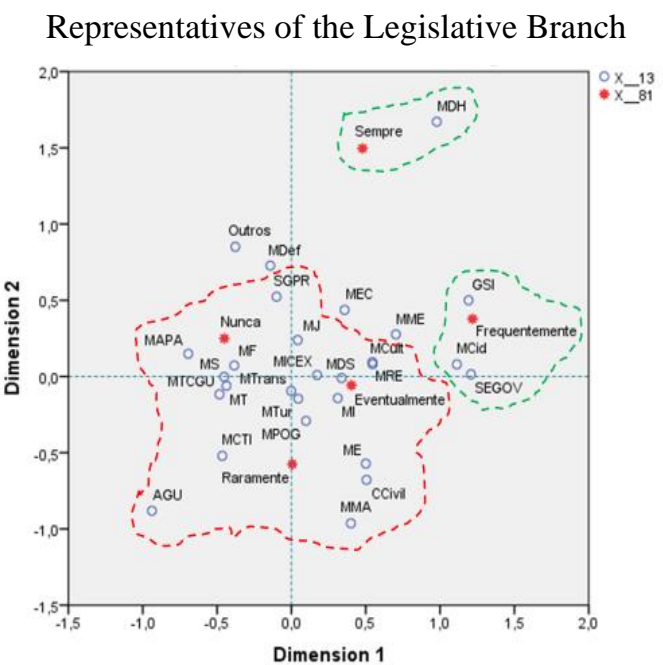

Civil society

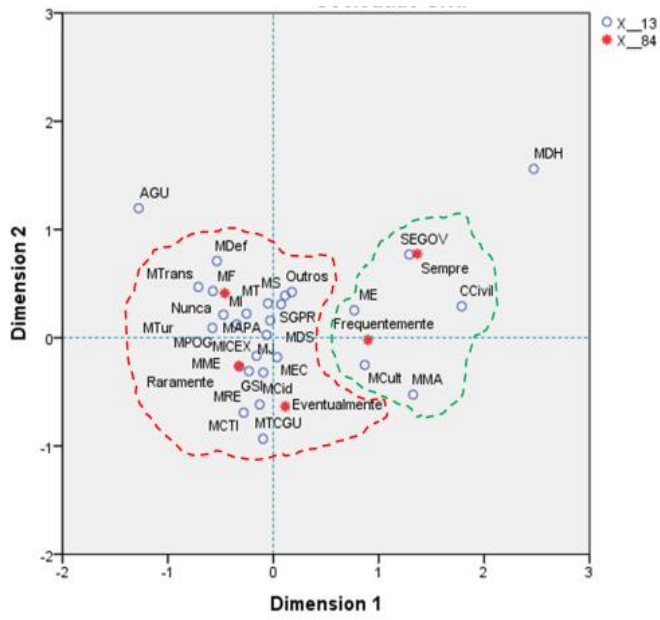

Participatory instances

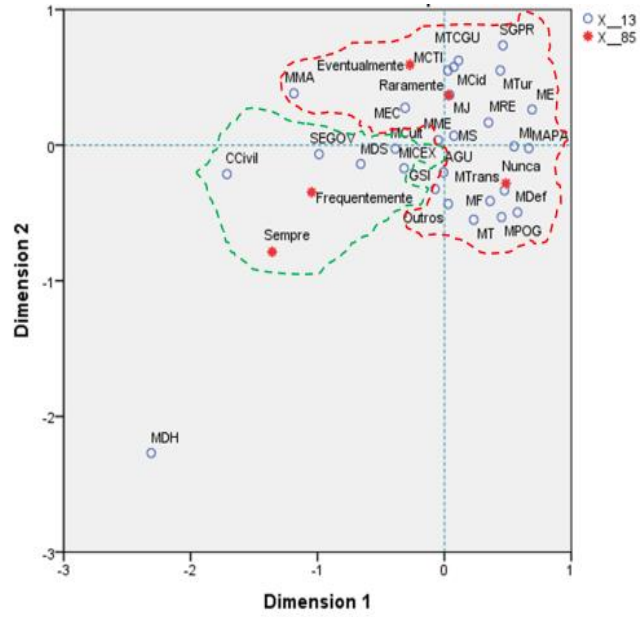

Source: Authors' elaboration.

These data lead us to conclude that political capacity is low and unequally distributed among federal government, a condition that challenges the governance of SDGs' Agenda and, consequently, policy integration.

\section{Institutional environment}

Macro challenges were raised by the interviewees during several instances of their interviews. Many agreed that the macro challenges are the frame of the medium and micro challenges already raised. The 2030 Agenda is within a context that cannot be dissociated from the challenges arising from a broader political-institutional context. 
The data collected in the interviews also reveal constraints to SDGs' implementation with respect to the institutional environment. These constraints may be divided into determining factors related to conducting the Agenda and conditioning factors intrinsic to the state structure. In the first category, the political stability level is indicated as a relevant constraint that challenges governance of the SDGs' implementation. Otherwise, in the second group, a coordination structure to reduce political interference and fragmentation and a strengthened tax structure were raised as critical constraints inherent to the Brazilian bureaucratic structure that should be developed to reinforce SDGs' governance systemically.

As Interviewee 4 described,

... we look at ... the effort of a joint work of several thematic areas, and the importance of the integrated policies ... I think that this is what this Agenda deals with when ... it says that it is indivisible, that it is integrated, when ... it brings a series of concepts ... the Brazilian political structure is very sedimented on the organization of coalition governments, separation of ministries, division between parties. It does not stimulate or favor, so to speak, an integrated policymaking environment.

Likewise, Interviewee 1 pointed out a paradox between coalition government structures on one side, and policy integration and systemic agency on the other:

Coalition governments create macro challenges, because ministries have suffered constant political fragmentation, generating autonomy, insulation, and results. But the political structure does not allow an interference of the center of government in sectoral agencies. If SDG 17 demands a systemic view of government, the state has to work in a systematic way, with a coordination between policies.

Therefore, on a systemic level, the institutional design is a critical condition to enforce the SDG Agenda governance, especially regarding how institutional political power and economic resources are shared among social groups.

\section{Leadership}

Interviews point out that one of the biggest challenges to governance of the SDGs' Agenda implementation is a lack of enforced leadership. Aligned with the perception that there is a fragile governance center for implementing the Agenda, there are those who also perceive "lack of clarity in the institutional arrangement for implementing the Agenda." Another interviewee argues that "No effective policy-inducing authority has been created. The National Commission is an [instance] that bears its legitimacy to seek a dialog, to foster partnerships, but it has no power to influence the ministries." 
Analysis of the interviews points to a common perception within federal bureaucracy that the SDGs Agenda is not a primary concern for the center of government. One interview summarizes this challenge: "The SDGs demand governance of central government as fundamental. Then, they demand a governance of sectoral public policies, and the duplication and overlapping of public policies by program. ... it is precisely the structuring of the center of government that will allow the integration of the SDGs into the ministries."

In short, interviews suggest that CNODS lacks the enforcement required to coordinate this Agenda effectively. Interviewees suggest that the Commission should have the autonomy to manage and coordinate the SDGs Agenda. Further, their perception is that this Agenda apparently is not a priority in the federal government's Agenda.

Levels of civil servants' involvement in the Agenda reflect that context. Figure 7 shows only $45.3 \%$ of civil servants of the Federal Direct Administration understand that the 2030 Agenda influences the public policy on which they work. Of these, 27.7\% report that they are unaware of the Agenda, and 11.6\% say the Agenda does not influence their work.

Among those who consider that the 2030 Agenda influences the public policy on which they work, the highest recognition of the Agenda is among the employees occupying the highest level of commissioned posts, especially DAS-5 (79.6\%) and DAS$6(66.7 \%)$, and among civil servants with the highest level of education.

Figure 7 - Civil servants' perception about how SDGs' Agenda influences their public policy

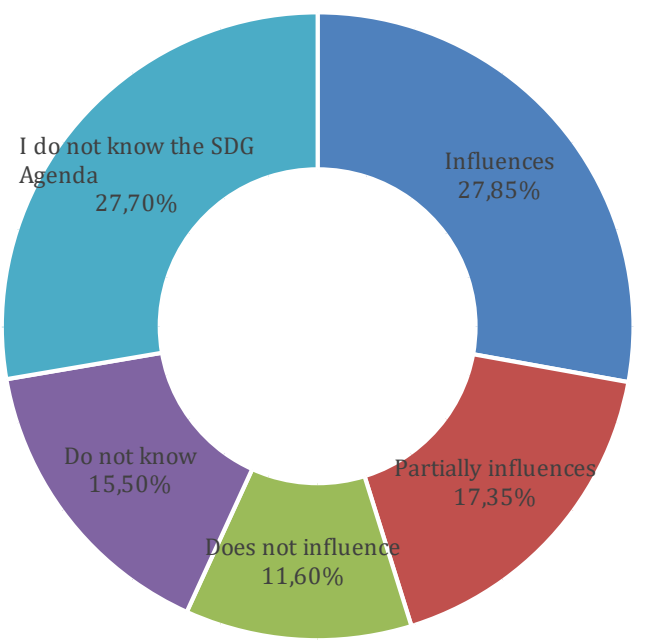

Source: ENAP, Research on Challenges and Conditions to SDGs' Agenda Implementation in Brazilian Federal Public Administration, 2018. 
As Figure 8 shows, data also reveal that despite top officials being more aware of the Agenda, a significant portion do not identify influence, do not know, or are unaware of the SDGs' Agenda. Thus, this data reinforces the problem of the lack of leadership pointed out by interviewees as a challenge to implementing the Agenda.

\section{Figure 8 - Level of perception about the influence of SDGS' Agenda on public policies' direction, based on the position the civil servant occupies}

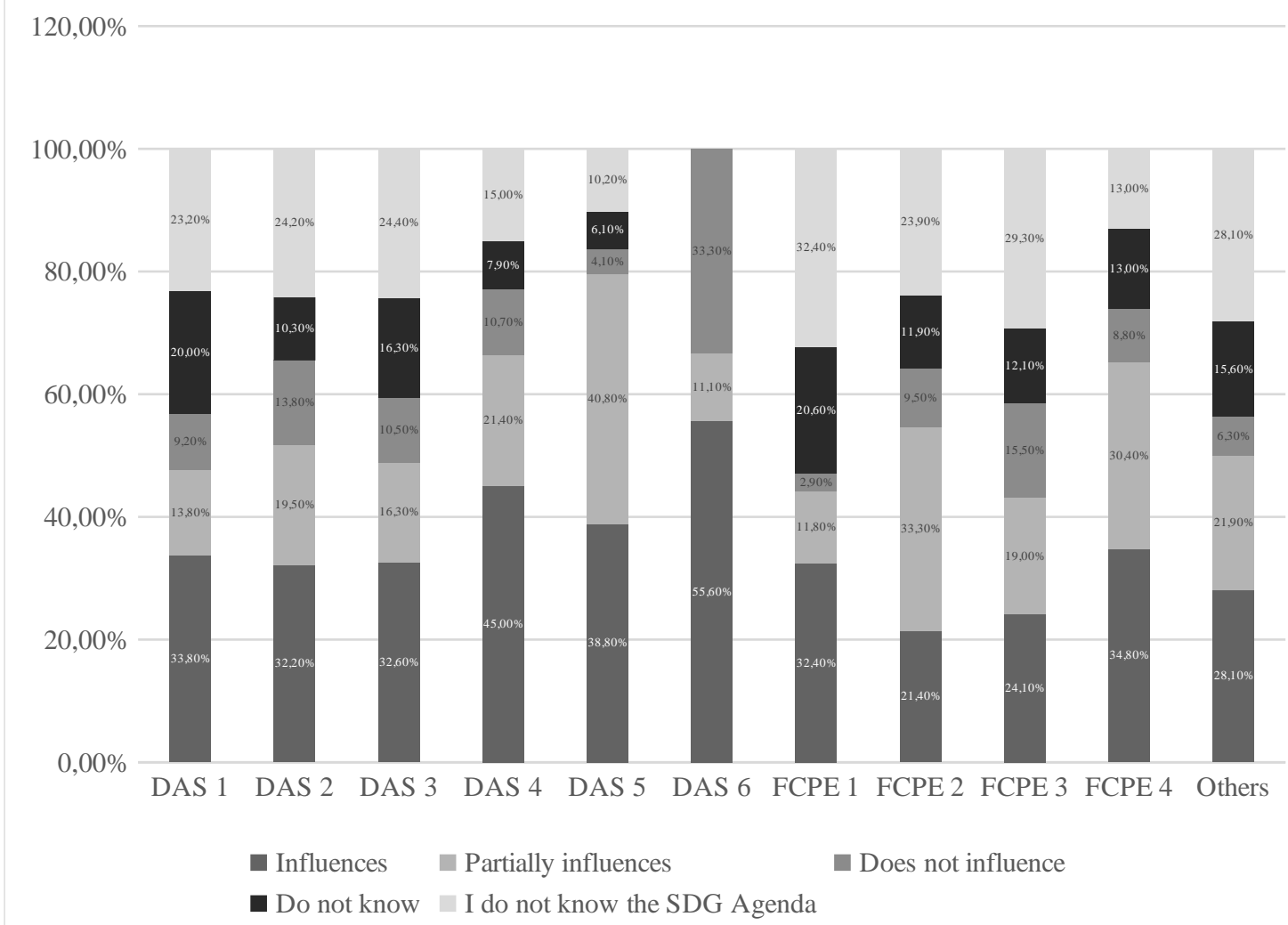

Source: ENAP, Research on Challenges and Conditions to SDGs'Agenda Implementation in Brazilian Federal Public Administration, 2018.

In agreement with this perception, several interviewees brought up the issue of leadership as one of the main determining factors for both the individual, organizational, and systemic level of implementation of the SDGs Agenda. As Interviewee 14 said, "Now one of the challenges to keep this agenda alive is to get people to buy this agenda. You have to have leadership. And you need to have that agenda kept alive and being pushed, because the moment you talk to people who barely know the Agenda ... where's the leadership?" 


\section{Discussion}

This investigation revealed that the lack of a clear and empowered leadership results in different understandings about the Agenda's relevance among the distinct actors, which in turn influences activity conducted for the Agenda within the federal government -including the Federal Court of Auditors that was confirmed in all interviews as one of the main sponsors of the 2030 Agenda in Brazil. Table 6 summarizes these different understandings as three main types: instrumentalist, ideational, and integrative.

Table 6 - Types of frameworks for actors' ideas and perceptions about the 2030 Agenda

\begin{tabular}{|c|l|l|}
\hline $\begin{array}{c}\text { Ideas about the } \\
\text { Agenda }\end{array}$ & \multicolumn{1}{|c|}{ Agenda opportunity in Brazil } & \multicolumn{1}{c|}{$\begin{array}{c}\text { Perception about the conditions of } \\
\text { implementation in Brazil }\end{array}$} \\
\hline Instrumentalists & $\begin{array}{l}\text { Develop a new model of } \\
\text { management and governance in the } \\
\text { federal administrative system from } \\
\text { existing management tools }\end{array}$ & $\begin{array}{l}\text { Need to develop a culture of evaluating } \\
\text { and monitoring public policies }\end{array}$ \\
\hline Ideational & $\begin{array}{l}\text { Recover the meaning of the } \\
\text { development of public policies } \\
\text { implemented in Brazil, to improve } \\
\text { what is available to promote real, } \\
\text { sustainable development }\end{array}$ & $\begin{array}{l}\text { Need to map what is already done, in } \\
\text { order to know the public policy system } \\
\text { possible integrations of government } \\
\text { actions ans anstic model for }\end{array}$ \\
\hline Integrative & $\begin{array}{l}\text { Mainstream the performance of the } \\
\text { Brazilian State as the main engine of } \\
\text { the integration of the Executive, } \\
\text { Legislative, and Judicial Branches } \\
\text { among the federal levels, and } \\
\text { between the government and civil } \\
\text { society }\end{array}$ & $\begin{array}{l}\text { Developing incentives of collaboration } \\
\text { between the different agencies, in } \\
\text { addition to creating collegiate } \\
\text { institutional arrangements that establish } \\
\text { a mediation of communication and } \\
\text { implementation of the Agenda }\end{array}$ \\
\hline
\end{tabular}

Source: ENAP, Research on Challenges and Conditions to SDGs' Agenda Implementation in Brazilian Federal Public Administration, 2018.

The first type, an instrumental understanding of the Agenda, lies in the expectation of using the Agenda as an opportunity to organize state objectives, processes, and tools for a common and shared orientation of governmental action. The second understanding, referred to as ideational, is concerned with the sense of development brought by the 2030 Agenda. That is, it maintains that adherence to the Agenda would imply redefining the development model of the Brazilian State and, for that, it would require not only a change of state operational structures, but also of any societal structure, thus involving State endogenous and exogenous conditions. Finally, the third understanding focuses on the integrative aspect of the Agenda as a way of coping with public policies' problems that 
are not restricted to the Federal Executive Branch's performance, but also to its performance with other levels of government, other branches, and actors of the state and civil society, as well as international actors. As Table 6 shows, each perception type carries a distinct set of requirements for governance.

This paper aimed to discuss the constraints of policy capacity and governance arrangements within the Brazilian federal government to implement SDGs. Engaging in the debate on collaborative governance, this investigation confirms Ansell and Gash (2007)'s governance model. The SDGs' Agenda requires higher levels of capacities, leadership, and proper institutional design to reach a form of collaboration that Howlett and Saguin (2018) identified as institutionalization, invoking strong coherence among public policies that lead to mutual, reinforcing cooperation toward shared goals.

Data analyzed in this investigation showed that analytical, coordination, and relational critical capacities are unevenly distributed across Brazilian federal agencies. Even though some islands of excellence can be perceived in specific dimensions, most of the agencies presented fragile conditions to reach the Agenda's high demands. Data also suggested some dysfunctionality in the Brazilian federal government's analytical capacity. Audit and legal systems seem not only to exert strong influence in analytical production but also deflect significant analytical effort from the federal government. That atypical pattern may explain the TCU's influence as a relevant sponsor of SDGs' implementation in Brazil. The investigation also sheds light on Brazilian bureaucracy's strong endogeneity and low levels of coordination and political capacity.

The institutional governance environment also was just as crucial for the Agenda's success. Fiscal and coordination structures that reduce political interference and fragmentation are an essential path for agenda implementation. Coordination tools were found; however, they are far from operating in the integrated manner demanded by SDGs' implementation. The fiscal and public budget structure, though, does not guarantee specific resources for SDGs' implementation. There are no legal prescriptions securing normative conditions, either. Brazil's current political instability and the upcoming government change already threaten the stability of international agreements and thus the 2030 Agenda continuity in Brazil.

Finally, leadership was pointed to as the main critical condition for implementing the SDGs in Brazil. This is probably because it positively can impact the other two conditions - that is, encouraging leadership can guarantee means of strengthening 
resources and providing necessary institutional changes. Data showed, however, that the present formal locus of leadership lacks empowerment to tackle this challenging process. According to the interviewees, leadership should be placed in the center of government. It was clear for them that the Agenda is not a government priority and its governance locus reflects that reality. So, despite all efforts put forth by the presidency of CNODS, there is still low recognition of the Agenda in bureaucracy - and different understandings about its importance concurs even among current sponsors of the SDGs.

\section{Conclusions and policy recommendations}

This research intends to contribute to the governance debate, examining the specific case of implementing the SDGs in Brazil. Despite the challenging scenario presented here, SDGs generally were perceived by key actors in the current Brazilian government as an opportunity to build coherence in Brazilian public policies. Future investigations can continue following the Agenda's trajectory for future government work. They also can consult other actors, especially external stakeholders that can provide varying perspectives on possible governance arrangements and conditions for implementing the SDGs. From a broader perspective, future investigations can compare countries that expand the use of collaborative governance to study existing interactions between the three types of conditions.

The results of this research show that SDGs require the production of policy coherence by strengthening policy capacities and building governance mechanisms that link global and local arenas for formulation and implementation, establish forms of interaction with society, and encourage interaction between government agencies and international organizations.

The findings of this research show that the Brazilian Federal Government has clusters of remarkably different capacities. Information systems are based on a range, going from audit reports or legal documents to information disseminated on the Internet and social networks. Analytical capabilities are disparate and poorly focused on evidence. Moreover, the relational capacities needed for the political construction of legitimacy lack a more interactive perspective based on building collaboration.

This research's theoretical contribution shows that governance depends on government agencies' interactive character - requiring more structural governmental 
instruments that promote coordination and strengthen policies' coherence, and instruments that promote analytical and relational capacities and strengthen collaboration mechanisms in the various institutional levels of policies. Finally, governance depends on political leadership to connect management mechanisms with the broader institutional environment, promoting authority based on democratic principles.

In this study on Brazil, implementing SDGs has several governance failures associated with a lack of leadership. Civil service capabilities are neither activated nor mobilized to implement the 2030 Agenda. Thus, governance is not restricted to the design of policy instruments. Governance also depends on political leadership and legitimacy mechanisms promoting the institutional conditions necessary for promoting sustainable development. Capacities can be activated or mobilized to achieve a policy objective, or simply ignored, impacting the results achieved in various ways.

Future research, in addition to addressing comparatively how capabilities are activated (or not), should address the causal problem of how capabilities impact public policy outcomes.

For Brazil, the evidence indicates that the SDGs' implementation depends on political leadership galvanizing the bureaucracy's capacities to implement policies coherently, by activating the following measures:

- Create coordination mechanisms in the government center.

- Enable analytical capabilities and mobilize data and information in an integrated manner.

- Promote agency interaction at various levels of implementation.

- Create forms of vertical and horizontal collaboration between government agencies, civil society organizations, and international organizations.

- Strengthen the institutional design of SDGs' governance.

- Promote forms of institutional learning that can lead to improvements in policy design in a manner that is coordinated and consistent with the overall development goals.

These recommendations are not exhaustive, and their relationship is not hierarchical. The 2030 Agenda, more than a global sustainability objective, is a window of opportunity to create a stream of institutional improvement of governance for Brazil's public policy. 


\section{References}

AgRANOFF, A. (2013). Collaborating to manage: A primer to the public sector. Georgetown University Press.

ANDERSON, C. J.; TVERDOVA, Y.V. (2003). Corruption, political allegiances, and attitudes toward government in contemporary democracies. American Journal of Political Science, 47 (1), 91-109. DOI: https://doi.org/10.1111/1540-5907.00007

ANSELl, C.; GASH, A. (2007). Collaborative governance in theory and practice. Journal of Publica Administration Research and Theory, 18 (4), 543-571, https://doi.org/10.1093/jopart/mum032

BARZELAY, M. (1992). Breaking through bureaucracy. A new vision for managing in government. Berkeley: University of California Press.

BERSCH, K.; PRAÇA, S.; TAYLOR, M. (2016). State capacity, bureaucratic politicization, and corruption in Brazilian State. Governance, 30 (1), 105-124. Doi: https://doi.org/10.1111/gove.12196

BraZIL. Negociações da Agenda de Desenvolvimento Pós-2015: Elementos Orientadores da Posição Brasileira. 2014. Available in: http://www.itamaraty.gov.br/images/ed_desenvsust/ODS-pos-bras.pdf.

BRAZIL. Decree N. 8.892, October 27, 2016. 2016. Creates the National Commission on Sustainable Development Goal. Available in: http://www2.camara.leg.br/legin/fed/decret/2016/decreto-8892-27-outubro-2016-783849publicacaooriginal-151328-pe.html.

BRAZIL. Relatório Nacional Voluntário sobre os Objetivos de Desenvolvimento Sustentável: Brasil / Secretaria de Governo da Presidência da República, Ministério do Planejamento, Desenvolvimento e Gestão. - Brasília: Presidência da República. 2017. Available in: http://www.secretariadegoverno.gov.br/snasdocumentos/relatoriovoluntario_brasil2017port.pdf.

Capano, G., Howlett, M, Ramesh, M. (2014). Re-thinking governance in public policy: Dynamics, strategy and capacities. In: CAPANO, G. et all. (ed.). Variaties of governance. Dynamics, Strategies, Capacities. New York: Springer.

CNODS (2017). Action Plan 2017-2019 Brazilian National SDG Commission. Available in: http://www4.planalto.gov.br/ods/publicacoes/plano-de-acao-da-cnods-2017-2019.

ENAP. Capacidades Estatais para Produção de Políticas Públicas: Resultados do Survey sobre o Serviço Civil no Brasil. 2018. Available in: http://repositorio.enap.gov.br/handle/1/3347

EUROPEAN COMMISSION (2015). Policy Coherence for Development. Luxembourg: [s.n.].

FGV DAPP, 2018. Ruediger, M. A. \& Jannuzzi, P. M. (2018). Políticas públicas para o desenvolvimento sustentável: dos mínimos sociais dos objetivos de desenvolvimento do milênio à agenda multissetorial e integrada de desenvolvimento sustentável. Rio de Janeiro: FGV DAPP.

FILGUEIRAS, F. (2018). Going beyond management: The agenda of democratic governance and the silenced change in Brazil. Revista de Administração Pública, 52 (1), 71-88. Doi: http://dx.doi.org/10.1590/0034-7612161430 
FREY, B. S.; STUTZER, A. (2000). Happiness, economy and institutions. The Economic Journal, n. 110, p. 918-938. Doi: https://doi.org/10.1111/1468-0297.00570

FUKUYAMA, F. (2013). What is governance? Governance - An International Journal of Policy, Administration, and Institutions, 26 (3), 347-368. Doi: https://doi.org/10.1111/gove.12035

GeORgeson, L. \& MASLIN, M. (2018). Putting the United Nations Sustainable Development Goals into Practice: A review of implementation, monitoring, and finance. Geo: Geography and Environment, 5( 1), 1-25, https://doi.org/10.1002/geo2.49

GRINDLE, M. (2004). Good enough governance: Poverty reduction and reform in development countries. Governance - An International Journal of Policy, Administration, and Institutions, 17 (4), 525-548. Doi: https://doi.org/10.1111/j.0952-1895.2004.00256.

Howlett, M.; RAMESH, M. (2014). The two orders of governance failure: Design mismatches and policy capacity issues in modern governance. Policy and Society, 33 (4), 317-327, https://doi.org/10.1016/j.polsoc.2014.10.002

Howlett, M.; Saguin, K. (2018). Policy capacity for policy integration. Implications for the Sustainable Development Goals. Lee Kuan Yew School of Public Policy Working Paper Series, n. 65 , p. $0-21$.

IBGE. Instituto Brasileiro de Geografia e Estatística. Sustainable Development Goals: Indicators. IBGE: Brasília. 2018. Available in: 〈https://ods.ibge.gov.br>.

Macedo, A. S.: Viana, R.; NAscimento, M. I. B. (2019). Capacidades Analíticas no Processo de Produção de Políticas Públicas: Quais Fontes de Evidências Utilizam o Serviço Civil da Administração Pública Federal? Administração Pública e Gestão Social, 4 (11): 1-22, https://doi.org/10.21118/apgs.v11i4.7199.

MARCh, J. G., OlSEN, J. P. (1995). Democratic governance. New York: Free Press.

MoORe, M. H. (1995). Creating public value: Strategic management in government. Cambridge: Harvard University Press.

MUNGIU-PIPPIDI, A. (2015). The quest for good governance. How Societies Develop Control of Corruption. Cambridge: Cambridge University Press.

MUNGIU-PIPPIDI, A. (2006). Corruption: Diagnosis and treatment. Journal of Democracy, 17 (3), 86-99.

Nilsson, M. et al. (2017). A Framework for understanding Sustainable Development Goal Interactions. A Guide to SDG Interactions: From Science to Implementation.

OLSEN, J. P. (2009). Democratic government, institutional autonomy and the dynamics of change. West European Politics, 32 (3), 439-465. Doi: https://doi.org/10.1080/01402380902779048

UNDP. Roteiro para a Localização dos Objetivos de Desenvolvimento Sustentável: Implementação e Acompanhamento no nível subnacional. 2016. Available in: http://www.br.undp.org/content/brazil/pt/home/library/ods/roteiro-para-a-localizacao-dosobjetivos-de-desenvolvimento-sust.html

Peters, B. G., Pierre, J. (2016). Comparative governance. Rediscovering the functional dimension of governing. Cambridge: Cambridge University Press. 
PETERS, B. G., PIERRE, J. (2008). Governance and social complexity. Statsvetenskaplig Tidskrift, 110 (3), 239-248.

Peters, B.G., (2015). Pursuing Horizontal Management: The Politics of Public Sector Coordination. Kansas: University Press of Kansas.

Pollitt, C.; BouckaeRt, G. (2004). Public management reform. A comparative analysis. Oxford: Oxford University Press.

PPA CidADÃo. Plano Plurianual do Governo Federal. 2016-2019. Available in: https://ppacidadao.planejamento.gov.br/sitioPPA/.

RHODES R. A. W. (2012). Waves of governance. In: LEVI-FAUR, D. (Ed.). The Oxford Handbook of Governance. Oxford: Oxford University Press, 33-48.

RHODES, R. A. W. (2007). Understanding governance: Ten years on. Organization Studies, 28 (8), 1243-1264. Doi: https://doi.org/10.1177/0170840607076586

RHODES, R. A .W. (1997). Understanding governance. Policy networks, governance, reflexivity, and accountability. Buckingham: Open University Press.

RosenAU, J. (1999). Toward an ontology for global Governance. In: HEWSON, M. \& SINCLAIR, T. J. (eds.). Approaches to global governance theory. Albany: State University of New York Press.

Rosenau, J. (1995). Governance in the 21st Century. Global Governance, 1 (11), 13-43.

Rothstein, B.; TeORELl, J. (2008). What is quality of government. A theory of impartial institutions. Governance - An International Journal of Policy, Administration, and Institutions, 21 (2), 165-190. Doi: https://doi.org/10.1111/j.1468-0491.2008.00391.x

SEGOv. Comissão Nacional ODS. 2017. Available in: http://www4.planalto.gov.br/ods/menude-relevancia/comissao-ods.

SEGOV. (2017). National Voluntary Report on the Sustainable Development Goals. Available in: <https://exposicao.enap.gov.br/items/show/562>.

Stone, D. (2019). Making Global Policy. Cambridge: Cambridge University Press.

StOKER, G. (1997). Governance as theory: Five propositions. International Social Science Journal, 50(155), 17-27. https://doi.org/10.1111/1468-2451.00106

STOKER, G. (2019). Embracing complexity: a framework for exploring governance resources. Journal of Chinese Governance 4 (2): 91-107. https://doi.org/10.1080/23812346.2019.1587859.

SÖRENSEN, E.; TORFING, J. (2005). Democratic anchorage of governance networks. Scandinavian Political Studies, 28 (3), 195-218. Doi: https://doi.org/10.1111/j.1467-9477.2005.00129.

TORFInG, J.; PETERS, B.G.; PIERRE, J. SÖRENSEN, E. (2012). Interactive governance. Advancing the paradigm. New York: Oxford University Press.

TCU. Federal Audit Office. Relatório de Levantamento. governança pública em âmbito nacional. análise sistêmica das oportunidades de melhoria constatadas. atuação conjunta dos tribunais de contas do brasil. recomendações aos órgãos governantes superiores. 2014. (TC 
020.830/2014-9). Available in:

https://portal.tcu.gov.br/lumis/portal/file/fileDownload.jsp?fileId=8A8182A24E08D405014E0D 42E95B3708

TCU. Federal Audit Office. Relatório de auditoria na preparação do governo brasileiro para implementação dos ODS. 2016. TC: 028.938/2016-0. Available in: https://portal.tcu.gov.br/lumis/portal/file/fileDownload.jsp?fileId=8A8182A25EC59C0F015F16 0B0E61349D.

TCU. Federal Audit Office. Relatório de auditoria. preparação dos sistemas de monitoramento do governo brasileiro para implementar e monitorar os objetivos de desenvolvimento sustentável (ods) 1, 2 e 5. recomendações. Second Instance Decision 298-2017. 2017. Available in: https://contas.tcu.gov.br/sagas/SvlVisualizarRelVotoAcRtf?codFiltro=SAGAS-SESSAO-

ENCERRADA\&seOcultaPagina $=S \&$ item0 $=582052$.

United NAtions (2015). The Millennium Development Goals Report. Available in: https://nacoesunidas.org/wp-content/uploads/2015/07/MDG-2015-June-25.pdf.

Yelland, P. (2010). An introduction to correspondence analysis. The Mathematical Journal, 12, $1-23$.

Wu, X.; RAmesh, M.; Howllet, M. (2016). Policy capacity: A conceptual framework for understanding policy competences and capabilities. Policy and Society, 34 (3), 165-171, https://doi.org/10.1016/j.polsoc.2015.09.001.

\section{Natália Massaco Koga}

(iD) https://orcid.org/0000-0003-0143-8373

She holds a law degree from the University of São Paulo (1999), a master degree in Public Administration and Government from the Getúlio Vargas Foundation - SP (2004) and a PhD in Political Science from the University of Westminster (2013). E-mail: natalia.koga @enap.gov.br

\section{Fernando Filgueiras}

iD https://orcid.org/0000-0001-9570-8113

School of Public Policy and Government, Getúlio Vargas Foundation (FGV), National School of Public Administration (ENAP) Brasília - DF - Brazil. E-mail: fernandofilgueiras@ hotmail.com

\section{Maricilene Isaira Baia do Nascimento}

https://orcid.org/0000-0003-2932-5135

$\mathrm{PhD}$. candidate in Political Science at the Institute of Political Science of the University of Brasilia, Brazil. Master in Political Science at the Federal University of Pará, Brazil.

E-mail: maricilene_isaira@hotmail.com

\section{Natasha Borali}

iD https://orcid.org/0000-0002-5531-1311

$\mathrm{PhD}$. candidate and Master in Public Administration and Government at the Fundação Getúlio Vargas. E-mail: boralinatasha@gmail.com

\section{Victor Bastos Lima}

(iD) https://orcid.org/0000-0002-3861-5436

Master in Public Policy Management from the University of São Paulo.

(USP). E-mail: viclima@gmail.com 


\section{Annex I: Organizations consulted}

\begin{tabular}{|c|c|}
\hline Abbreviation & Agencies \\
\hline AGU & National Attorney General \\
\hline Chief of Staff Office & Chief of Staff Office \\
\hline General Sec. PR & Presidency’s General Secretariat \\
\hline Gov. Sec. PR & Presidency's Government Secretariat \\
\hline GSI & Security Cabinet of the Republic Presidency-GSI/PR \\
\hline Itamaraty/MRE & Ministry of Foreign Affairs \\
\hline MAPA & Ministry of Agriculture, Livestock and Food Supply \\
\hline MCid & Ministry of Cities \\
\hline MCTI & Ministry of Science and Technology \\
\hline MD & Ministry of Defense \\
\hline $\mathrm{MDH}$ & Ministry of Human Rights \\
\hline MDIC & Ministry of Development, Industry and Commerce \\
\hline MDS & Ministry of Social Development \\
\hline $\mathrm{ME}$ & Ministry of Sports \\
\hline MEC & Ministry of Education \\
\hline $\mathrm{MF}$ & Ministry of Finance \\
\hline MI & Ministry of Integration \\
\hline Minc & Ministry of Culture \\
\hline MJ & Ministry of Justice \\
\hline MMA & Ministry of Environment \\
\hline MME & Ministry of Mining and Energy \\
\hline MP & Ministry of Planning, Development and Management \\
\hline MS & Ministry of Health \\
\hline MTFCGU & Ministry of Transparency and Comptroller General's Office \\
\hline MT & Ministry of Labor \\
\hline MTPA & Ministry of Transports, Ports and Civil Aviation \\
\hline MTUR & Ministry of Tourism \\
\hline
\end{tabular}


